\title{
A holistic sustainability assessment of organic (certified and non-certified) and non-organic smallholder farms in Kenya
}

\author{
Juliet Wanjiku Kamau ${ }^{1}$ (D) . Christian Schader ${ }^{2}$. Lisa Biber-Freudenberger ${ }^{1}$. \\ Till Stellmacher ${ }^{1}$. David M. Amudavi ${ }^{3}$. Jan Landert ${ }^{2}$. Johan Blockeel ${ }^{2}$. \\ Cory Whitney $^{1,4} \cdot$ Christian Borgemeister $^{1}$
}

Received: 8 May 2019 / Accepted: 3 August 2021 / Published online: 2 September 2021

(C) The Author(s) 2021

\begin{abstract}
The introduction of organic farm management practices in sub-Saharan Africa could act as a lever for supporting regional sustainable development. In this study, we sought to assess the sustainability performance of organic (certified and non-certified) and non-organic farms in the dry Kajiado County and the wet Murang'a County in Kenya, based on four sustainability dimensions: Good Governance, Environmental Integrity, Economic Resilience and Social Well-Being. We collected household survey data from 400 smallholder farms, which were formally characterized into five types (mixed organic and conventional, certified organic, organic, conventional, and subsistence farms). We used multivariate analysis of variance, linear fixed-effects and general linear models to examine differences in sustainability performance. Model results indicate that all farms lack reliable farm management information and that only limited knowledge, skills and social security exist for farmers and farm workers. Comparison of the five farm types indicates no significant differences in their sustainability performance. Nonetheless, certified organic farms had better sustainability performance than non-certified farms due to higher economic resilience, environmental integrity, better support and training for workers. However, except for avoiding the use of agrochemicals in certified farms, there is relatively little difference in the farm management practices across farm types. Our results also indicate that farms in Murang'a were more sustainable than those in Kajiado due to better regional land-tenure security and conflict resolution mechanisms, soil and water conservation measures, and farm commercial viability. Nonetheless, unlike Kajiado, farms in Murang'a showed a tendency toward poor animal husbandry practices which affects overall animal welfare, limited credit uptake and market involvement. The results of this study can support decision making to identify appropriate interventions for improving sustainability in smallholder farms.
\end{abstract}

Keywords SAFA guidelines · Organic agriculture - Sub-Saharan Africa · Certification · Indicators

Juliet Wanjiku Kamau

wanjikuj2003@yahoo.com

Extended author information available on the last page of the article 


\section{Introduction}

Agriculture, mainly practiced by rural smallholder farmers, is still the mainstay of most people in sub-Saharan Africa (SSA), and the main driver of socio-economic development (Altieri, 2009; Davis et al., 2017; Salami et al., 2010). Consequently, sustainable agriculture has been identified as a crucial element for promoting sustainable development in SSA (Conceição et al., 2016; Grenz et al., 2009). Smallholder farms, defined by landholding size, constitute the majority of farms in the world, and in SSA around 50\% of the smallholders (i.e. cultivating up to $2 \mathrm{ha}$ ), live in absolute poverty, despite being primary food producers and managers of natural resources (Altieri, 2009; Salami et al., 2010; Samberg et al., 2016). This study focuses on Kenya where over a third of the population depends on agriculture to sustain their livelihood, and nearly half of the population lives in poverty and is food insecure (GoK, 2009; WFP, 2016).

Supporting smallholder farmers in Kenya and other SSA countries is considered a crucial part of the strategies addressing natural resource depletion and degradation, decreasing agricultural productivity, food insecurity, poverty, and for adapting to population growth, climate change, urbanization and land-use change (De Jager et al., 2001; Giller et al., 2009). However, at present, given the socio-economic, demographic and ecologic constraints, smallholder farms in SSA are showing a tendency toward unsustainable practices (Cohn et al., 2017; Salami et al., 2010).

In the attempt to achieve the United Nations Sustainable Development Goals (SDGs) (UN General Assembly, 2014), smallholder farmers are expected to play an important role through their agricultural and land-use practices (Conceição et al., 2016; Grenz et al., 2009). The definition of sustainable development (used here interchangeably with the term 'sustainability') is generally agreed to be based on three key dimensions: environmental, economic and social (Keeble, 1988; Pretty, 1995; Schaller, 1993). We use the sustainability definition from the guidelines for Sustainability Assessment of Food and Agriculture Systems (SAFA Guidelines) by the Food and Agriculture Organization of the United Nations (FAO) (FAO, 2014), which includes the fourth dimension of good governance (Schader et al., 2016).

\subsection{Organic agriculture in sub-Saharan Africa}

Organic agriculture (OA) is being promoted as a sustainable farming system in SSA through the "Ecological Organic Agriculture" (EOA) initiative of the African Union (Niggli et al., 2016). Organic smallholder farms in SSA countries can be grouped into certified organic, organic non-certified and mixed organic-conventional. Non-organic farms include conventional and low-input-output systems with no use of agrochemicals at all. The latter are often described as 'organic by default' (Bennett \& Franzel, 2013). Certified organic farmers market their products based on standards of international or national certification schemes that follow the general rules of OA. The non-certified organic farmers adhere to many organic principles but are not formally certified as OA (Badgley et al., 2007).

In addition to being promoted by the African Union and other non-state entities, the rise of OA in Africa is being driven by an increasing demand for organically produced products in developed countries. There is also a growing demand for these products in Africa driven by changing local consumer preferences as their living standards improve and concerns about food safety issues grow. 
In Kenya, the practice of organic agriculture has gained popularity, triggered by growing demand in organic products in the region as well as internationally. There is also an established regional certification standard in the region called the East Africa Organic Product Standard (EAOPS) (Ayuya et al., 2015; Ndukhu et al., 2016; Schwindenhammer, 2016). Kenyan farmers can grow organic produce through contractual agreements with private companies that facilitate certification and export of the produce. Farmers can also organize themselves in groups such as participatory guarantee systems (PGS) that are supported by local organic initiatives like the Kenya Organic Agriculture Network (KOAN) to get certified. The produce by PGS farmers is mainly sold in local or neighbouring markets, such as the East African region. The products destined for international markets are mainly high value crops like coffee, tea, fruits, nuts and herbs. For the local Kenyan or regional East African market, there is a wide variety of crop and animal products sold including honey, eggs, cereals, vegetables and root tubers (Ayuya et al., 2015; Katto-Andrighetto, 2013; Schwindenhammer, 2016).

Organic and other agricultural certification schemes usually attempt to increase sustainability (Raynolds et al., 2007) by following specific regulations such as those prohibiting the use of chemically treated planting material, genetically modified organisms (GMOs), synthetic fertilizers and pesticides as well as non-organically produced feed and prophylactic use of antibiotics for livestock.

On the one hand, the sustainability of OA is contested. For instance, OA is criticized for generating lower yields, which can translate into lower profitability and inadequate food production compared to conventional agriculture (Meemken \& Qaim, 2018). On the other hand, OA has been credited for its potential to increase biodiversity and to improve soil and water quality among other social and ecological benefits (Kamau et al., 2019; Muller et al., 2017). In SSA, organic certification has been found to improve profitability, increase social capital, reduce poverty and improve standards of living (Ayuya et al., 2015; Bolwig et al., 2009; Ndungu et al., 2013). Due to the divergent views on the sustainability of OA in science and practice, better insight into the potential of OA practices in contributing to sustainable development in SSA is needed.

\subsection{Agricultural approaches to sustainable development: sustainability assessments and tools}

Sustainability assessments based on comprehensive frameworks can support decision making by indicating ways to decrease the negative impacts of agriculture on natural ecosystems, to improve food security and to reduce poverty (Angevin et al., 2017; de Olde et al., 2016). Indicators used in sustainability assessments and tools based on these indicators vary widely in purpose (e.g. research, extension, policy and planning), assessment level (e.g. product/supply chain, farm), dimension (e.g. environmental and/or economic and/or social), intended user, assessment approach (e.g. self-assessment, external auditor), and specificity level (e.g. sector, country or region specific) (de Olde et al., 2016; Schader et al., 2014). Due to this diversity in assessment tools, comparability of data and results is challenging. Although one-size-fits-all solutions are not possible, there is a consensus regarding the need for harmonizing approaches, criteria and indicator sets to enhance the comparability of different sustainability assessment methods (Dantsis et al., 2010; Sachs et al., 2010).

Several frameworks have been developed and used as a basis for selecting indicators to assess sustainability. In agricultural systems for example, the SAFA Guidelines by the 
FAO (2014) and the Sustainability Assessment of Farming and the Environment Framework (Van Cauwenbergh et al., 2007) have been used. Further tools and approaches include the Life Cycle Sustainability Assessment (LSCA) (Guinée et al., 2011), and the ResponseInducing Sustainability Evaluation (RISE) (Schader et al., 2014). More tools for sustainability assessment are well documented in literature and their number is rising (Arulnathan et al., 2020; Schader et al., 2014).

The divergent definitions of sustainability, dimensions and indicators in studies of sustainability in smallholder farming in Kenya limits the comparability of their results and conclusions. Sustainability assessments of smallholder farms in Kenya are often based on varying aspects, (sub-) themes and indicators (De Jager et al., 2001; Grenz et al., 2009; Nzila et al., 2012; Onduru \& Du Preez, 2008; Shepherd \& Soule, 1998; Spaling et al., 2011). For instance, a study comparing low external input and organic management systems to those of conventional smallholders in Machakos County, eastern Kenya, a relatively dry region, used indicators related to environmental and economic aspects of sustainability (De Jager et al., 2001). Other studies in Embu County, also in eastern Kenya (Onduru \& Du Preez, 2008), as well as in a relatively humid area in Laikipia County, central Kenya (Grenz et al., 2009), used indicators based on the three main dimensions of sustainability (environmental, economic and social).

In this study, we seek to close the gap in sustainability assessments by demonstrating a comprehensive approach to produce nationally and internationally comparable results along food and agricultural value chains following the SAFA guidelines (FAO, 2014). Additionally, we seek to assess the sustainability of organic and non-organic smallholder farms in two biophysically different counties in Kenya.

Our study was intended to answer the following research questions: (1) What are the characteristic patterns and features of the sustainability performance of Kenyan smallholder farms? (2) Do differences exist in the sustainability performance of smallholder farms practicing organic (certified or non-certified) compared to non-organic (i.e. conventional or low-input 'organic by default') farm management? (3) Do differences exist in sustainability performance between the two biophysically distinct Kenyan counties? We present a farm-level assessment of sustainability in two representative regions in Kenya. Most of the content of this paper is also part of a doctoral thesis (Kamau, 2018).

\section{Materials and methods}

\subsection{Study area}

We sought to assess the sustainability of Kenyan smallholder farms while taking into account the heterogeneity of the farms and biophysical differences (e.g. climate and soils), which is recommended in the assessment of agricultural sustainability (Chopin et al., 2017). We chose two counties to represent distinct climatic classifications in Kenya. The first was semi-arid land (ASAL) receiving between 150 and $1100 \mathrm{~mm}$ of rainfall annually and represents $80 \%$ of the land in Kenya. For this, we chose Kajiado County in south-western Kenya in the ASAL region. The main livelihood activities in Kajiado are pastoralism, conservation of wildlife and crop farming (KCDP, 2013). The certified organic farmers surveyed in Kajiado are members of PGS groups supported by KOAN. These farmers sell their produce at local markets for the prevailing prices, or at premium prices in coordinated markets in Nairobi or other areas within East Africa. 
The second category is humid and semi-humid regions receiving between 600 and $2700 \mathrm{~mm}$ of rainfall annually. Murang'a County in central Kenya is found in the humid to semi-humid region. The main livelihood activities are crop farming and animal husbandry (MCDP, 2013). The certified organic farms in this county are usually third-party certified by organizations such as the Swiss IMO and others. Certification is regulated through contracts with private companies that obtain and market the farms' produce. These companies pay for the certification costs and facilitate the transformation of the farm through farmer training, hiring labour for harvesting, and marketing the farmers' products at a premium prices (Kamau, 2018; Kamau et al., 2018).

\subsection{General approach to the selection of farm and study area}

In this study, we applied a typology of smallholder farms (Kamau et al., 2018) that captures farm heterogeneity based on structural, functional and socio-economic aspects. The typology includes five farm types, which can be described as; self-subsistence farms (Type 1), mixed organic and conventional (Type 2), organic non-certified (Type 3), conventional (Type 4), and certified organic (Type 5) (see Table 1). To further study if there was any effect of organic certification, we grouped the farms that were known to be certified organic and compared them to the rest of the farms (i.e. organic non-certified, conventional, mixed and the low-input 'organic-by-default' farms.

We used the results of a multi-stage sampling procedure that had been applied to select the study areas and farms (Kamau et al., 2018) with a sampling frame provided by the agriculture departments of each county. In addition, the national organic initiative KOAN linked us to their local contacts who issued lists of smallholder farmers that were registered with them. Using the Probability Proportional to Size (PPS) sampling procedure (Skinner, 2016), 33\% certified organic farms $(n=180)$ and $\sim 66 \%$ non-certified farms $(n=345)$ had been randomly selected for the earlier study (see Kamau et al., (2018) for details). In the present study, about the same ratio of certified organic $(n=120)$ to non-certified farms ( $n=280)$ from the Kamau et al., (2018) were sampled. Of the 400 smallholder farms sampled, 211 were in Murang'a, of which $38 \%$ were certified organic, and 189 were in to Kajiado, with $\sim 21 \%$ certified organic.

\subsection{SAFA guidelines and SMART-farm tool}

In this study, we investigated the aspect of sustainability performance based on the SAFA Guidelines that consider four dimensions of sustainability: Environmental Integrity, Economic Resilience, Social Well-Being and Good Governance. These four dimensions consist of a total of 21 themes and 58 subthemes. Each subtheme has defined objectives meant to assess the sustainability of operators in the agricultural and food value chain (FAO, 2014), (Fig. 1).

We used the Sustainability Monitoring and Assessment RouTine (SMART)-Farm Tool, which operationalizes the SAFA Guidelines following a similar ordered format of dimensions, themes and subthemes. The tool utilizes an impact matrix with 327 indicators of sustainability. In this matrix, the indicators have 1769 interconnections with the 58 subthemes (Schader et al., 2016). The impact matrix is used to compute the degree of sustainability achievement and measures the degree of goal achievement for each sustainability subtheme described in the SAFA Guidelines on the basis of multi-criteria assessments. Results are normalized to percentage scores ranging from 0 to $100 \%$ indicating 


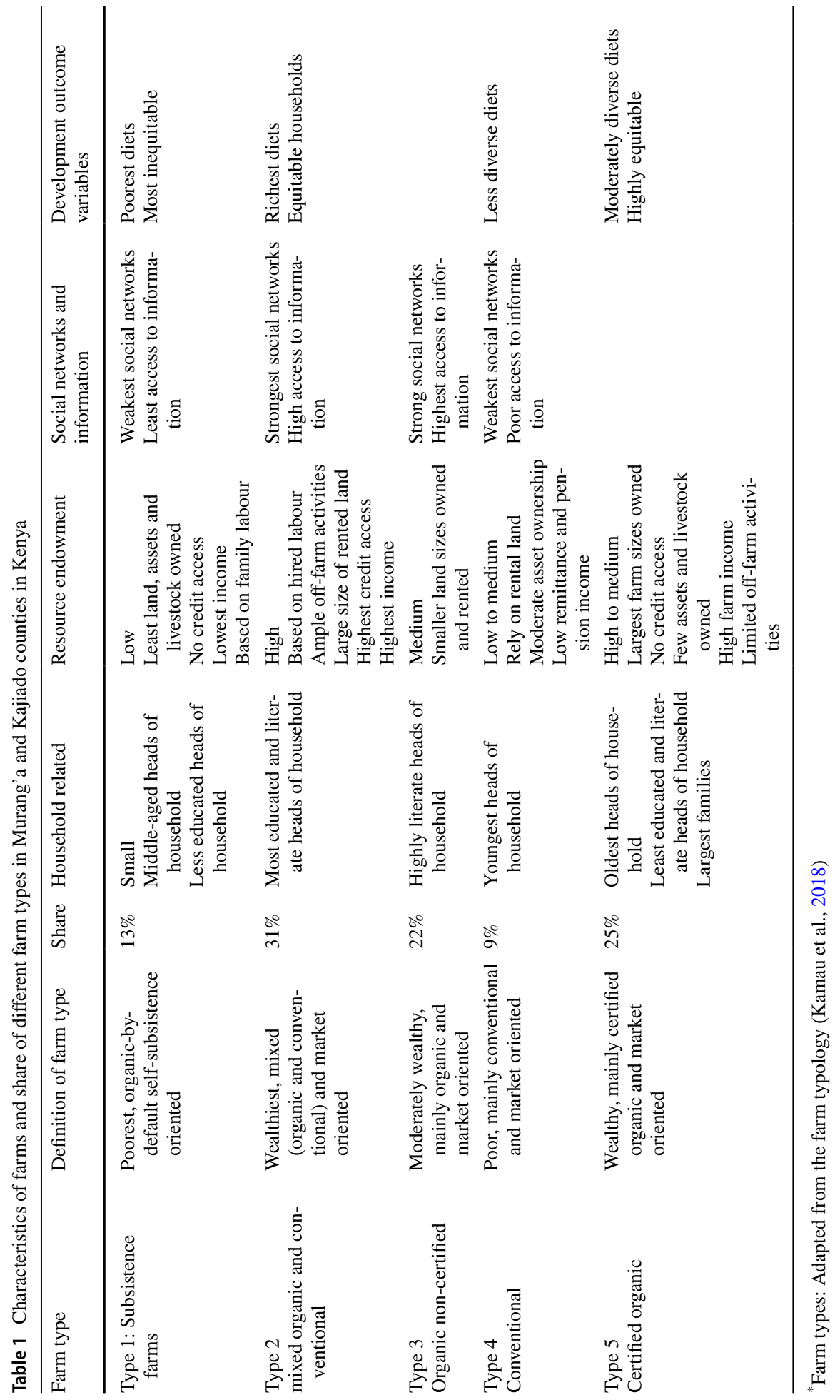




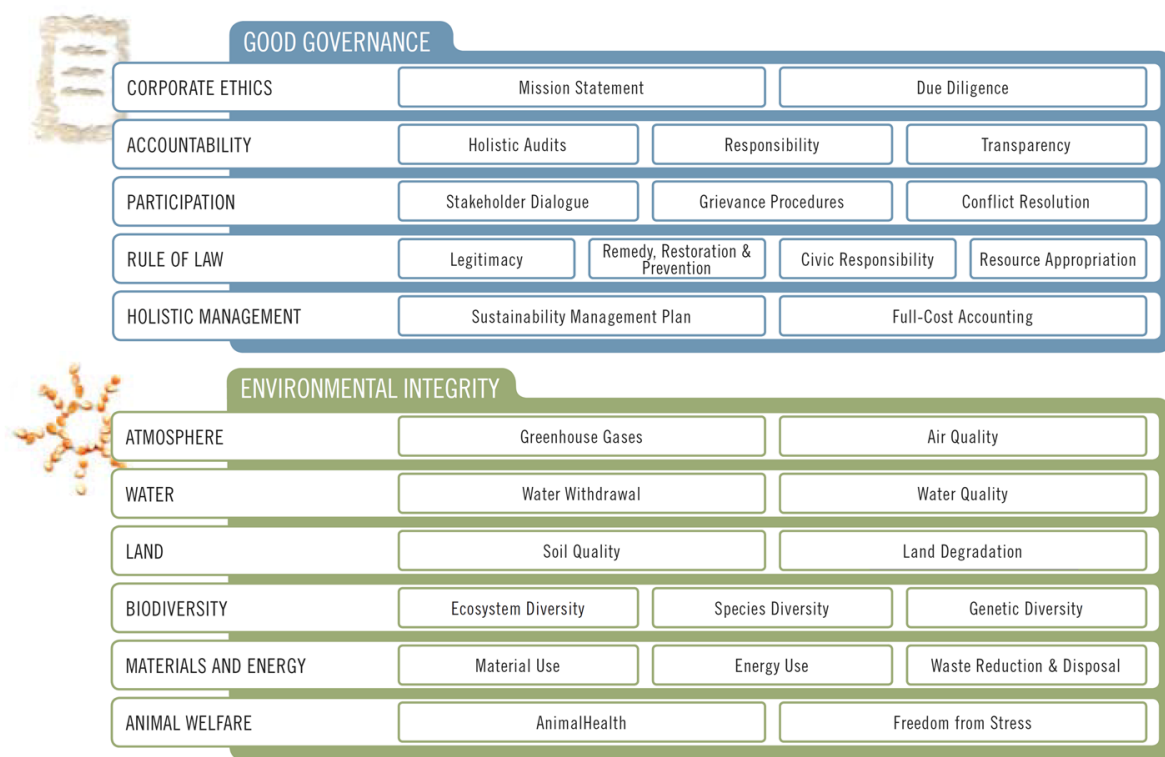

\begin{tabular}{|c|c|c|c|c|c|c|}
\hline INVESTMENT & Internal Investment & \multicolumn{2}{|c|}{ Community Investment } & \multicolumn{2}{|c|}{ Long-Ranging Investment } & Profitability \\
\hline VULNERABILITY & $\begin{array}{l}\text { Stability of } \\
\text { Production }\end{array}$ & Stability of Supply & \multicolumn{2}{|c|}{ Stability of Market } & Liquidity & Risk Management \\
\hline PRODUCT QUALITY \& INFORMATION & \multicolumn{2}{|c|}{ Food Safety } & \multicolumn{2}{|c|}{ Food Quality } & \multicolumn{2}{|c|}{ Product Information } \\
\hline LOCAL ECONOMY & \multicolumn{3}{|c|}{ Value Creation } & \multicolumn{3}{|c|}{ Local Procurement } \\
\hline
\end{tabular}

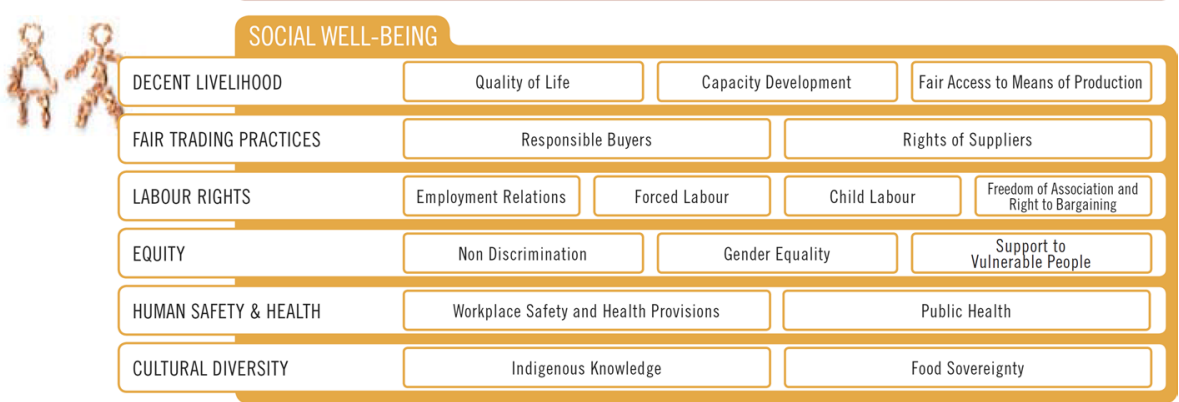

Fig. 1 Outline of dimensions, themes and subthemes from the guidelines for Sustainability Assessment of Food and Agriculture Systems (SAFA). Source: Food and Agriculture Organization of the United Nations (FAO) 2014

worst and best performance, respectively. A relevance check is integrated into the tool to enable automatic selection of relevant indicators for standardizing the questionnaire and thus ensuring comparability between different regions (e.g. temperate, tropical), farm sizes (e.g. large, medium, smallholder) and specific farming systems or components (e.g. crop farming, livestock, arable farming, pesticide or fertilizer use, and labour). Each indicator has a weight on a certain subtheme. These weights are expressed on a scale of $-100 \%$ to $+100 \%$ indicating the size of the negative or positive impact of a specified indicator on a 
subtheme. The impacts of each indicator in relation to a subtheme were predefined, and experts estimated their magnitude/weight in a Delphi process.

To combine the performance of the different indicators, we aggregated the outcome of the indicator scores up to the subtheme level using a weighted sum algorithm. The sum of the performance rating of respective indicators in relation to the sum of impact weights of respective indicators provides the sustainability score at the subtheme level and is termed as degree of goal achievement (Eq. 1).

$$
\operatorname{DGA}_{i x}=\sum_{n=1}^{N}\left(\left|\mathrm{IM}_{n i}\right| \times \mathrm{IS}_{n x}\right) / \sum_{n=1}^{N}\left(\left|\mathrm{IM}_{n i}\right| \times \mathrm{IS} \max _{n}\right) \forall \quad i \text { and } x
$$

where $\mathrm{DGA}_{i x}$ is the degree of goal achievement of a farm $x$ with respect to a subtheme $i$; $\mathrm{IM}_{n i}$ is the impact weight of indicators $n(n=1$ to $N)$ that are relevant to the subtheme $i$; IS $_{n x}$ is the performance of a farm $x$ in relation to an indicator $n$; $\operatorname{ISmax}_{n}$ is the maximum possible performance of an indicator $n$. The tool generates sustainability reports for each farm (Schader et al., 2016).

To determine the performance of each farm in relation to each relevant indicator and with respect to a given subtheme, we calculated the RIi value according to Eq. 2:

$$
\mathrm{RI}_{i}=\left(\left|\mathrm{IM}_{n i}\right| \times \mathrm{IS}_{n x}\right) \forall \quad i \text { and } x
$$

where $\mathrm{RI}_{i}$ is impact rating representing the product of $\mathrm{IM}_{n i}$ and $\mathrm{IS}_{n x}$. The $R I$ value helped us to understand which indicators contributed to poor performance or large differences in the performance of the subthemes.

\subsection{Application of SMART-Farm Tool in data gathering and analysis}

The collection of data for this study started in May and ended in June 2016 using the SMART-Farm Tool questionnaire (Version 4.0). Previous to the start of the fieldwork, we chose a group of eight auditors from various institutions in academia and farm extension. All had an agronomic background and no prior knowledge of the SMART-Farm Tool. Together we did a two-week extensive theoretical and practical training program on, the SAFA Guidelines, sustainability assessments, and the process of assessing a farm. We also performed pre-tests and a relevance check of the SMART-Farm Tool questionnaire on a few farms to assist in the interpretation of indicators. Based on the relevance check, between 284 and 318 indicators (from the SMART-Farm Tool pool of 327) were found to be relevant and applied for the sample farms.

We began each farm visit with an introduction by the auditors during which general data about the farm was collected. We followed this with a tour of the farm and concluded with a follow-up interview session. The interview was used to additionally verify and check the plausibility of the observations. To reduce the risk of interviewee fatigue, the interview was punctuated by breaks.

We reviewed the questionnaires to ensure that the interviews were exhaustive and the indicators had been assessed correctly and discussed any inconsistencies or gaps in rating indicators. We followed up and edited where necessary. We also carried out plausibility checks on selected indicators that had divergent responses with the help of an experienced external auditor. In cases where data points were not plausible, the respective auditor was asked to clarify, and if there were data errors, to directly correct them. The SMART-Farm Tool automatically calculated the sustainability performance per subtheme, i.e. $D G A_{i x}$ 
degree of goal achievement. These scores were then analysed further as discussed in the following section.

\subsection{Output of SMART-farm tool analyses}

This study uses the term 'farm type/s' to refer to the five categories or types of farms identified in the previous study. A distinction is also made between farms that are certified and those that are not certified (i.e. certification status). The non-certified farms include organic non-certified, mixed, conventional and 'organic-by-default' farms (Table 1). Although we refer to the latter as 'organic by default', in this study we do not consider these subsistence low-input-output systems as practicing organic farming. Their farming practices merely have partial resemblance to organic farming.

We analysed the output of the SMART-Farm Tool, which comprises scores of degree of goal achievement per subtheme $\left(\mathrm{DGA}_{i x}\right)$ as well as the calculated RI values for the indicator scores, in STATA version 14 (StataCorp, 2015). Using multivariate analyses of variance (MANOVA) and multiple linear fixed-effects models, we tested whether farm type (Type 1 to 5) or farm certification status (certified organic versus non-certified) and county (Kajiado versus Murang'a) or the association of the factors had a significant impact on the assessed sustainability subthemes. We chose the preceding multivariate linear approach MANOVA to better control our Type I error rate (Ling, 2011) without the need for any additional adjustment on the 58 succeeding linear models. We used the Pillai's trace test statistic produced by a MANOVA for indication of the influence of the factors on the subthemes.

We conducted two separate MANOVAs: one examining the association between farm type and county and the other examining the association between certification status and county. We also focused on two-way interactions (i.e. farm type $\times$ county or certification status $\times$ county) because certified organic farms were found across different farm types (Table 1). We tested the multivariate normality of the residuals, as an assumption for the multivariate normality for the MANOVA (Mardia et al., 1979). As the multivariate normality must be tested in each factor, the sample size was not sufficient (i.e. small number of observations per group) to provide the testing of the covariance matrices (singular), which in turn inhibits a global test. Therefore, we corrected for multiple testing and used Bonferroni correction (not trivial covariances). The result did not lead to any rejection of any variable under the normality assumption.

Next, if factors significantly impacted on a specific subtheme, least significant difference LSD pairwise post hoc tests were conducted to compare the means of the different factor levels at $p<0.05$. Although no adjustments are needed for planned comparison (e.g. comparisons after a preceding global test in our case) (Milliken \& Johnson, 2009), Fisher's protected LSD correction was used due to conventional procedures.

A meaningful interpretation of the results of the SMART-Farm Tool requires the identification of the factors driving the sustainability scores in these subthemes (Schader et al., 2016). Thus, in the follow-up step, we revisited the performance of indicators relevant for each subtheme and represented by the $R I$ value. We used generalized linear models (GLMs) with binomial family and logit link to examine the existence of significant differences in sustainability performance of the indicator using average $R I$ scores with respect to farm type, certification status and county. However, since numerous indicators affected the performance of a given subtheme, we only report and discuss indicators with high impact weights (i.e. $\geq 0.6$, where $0=$ least $1=$ highest). 


\section{Results and discussion}

\subsection{Overall sustainability performance}

The overall sustainability performance of the smallholder farms $(D G A)$ in the two counties followed a similar pattern as shown by averages of results generated by the SMART-Farm Tool (Figs. 2, 3, 4, and 5). The worst performance in all farms was in the dimension Good Governance, especially in the themes Accountability and Holistic Management (Fig. 2). This was mainly due to the disregard of external costs in the accounting procedure, lack of an explicit sustainability plan, lack of farm certification in the use of agrochemicals as well as missing publicly disclosed written sustainability reports (Appendix A, Table S1).

\subsubsection{Farm management and accountability}

According to the SAFA Guidelines, the Holistic Management theme considers the external effects of the farm activities in accounting and decision making, while the Accountability theme relates to disclosure and availability of correct and complete information about all aspects of the farm's performance (FAO, 2014).

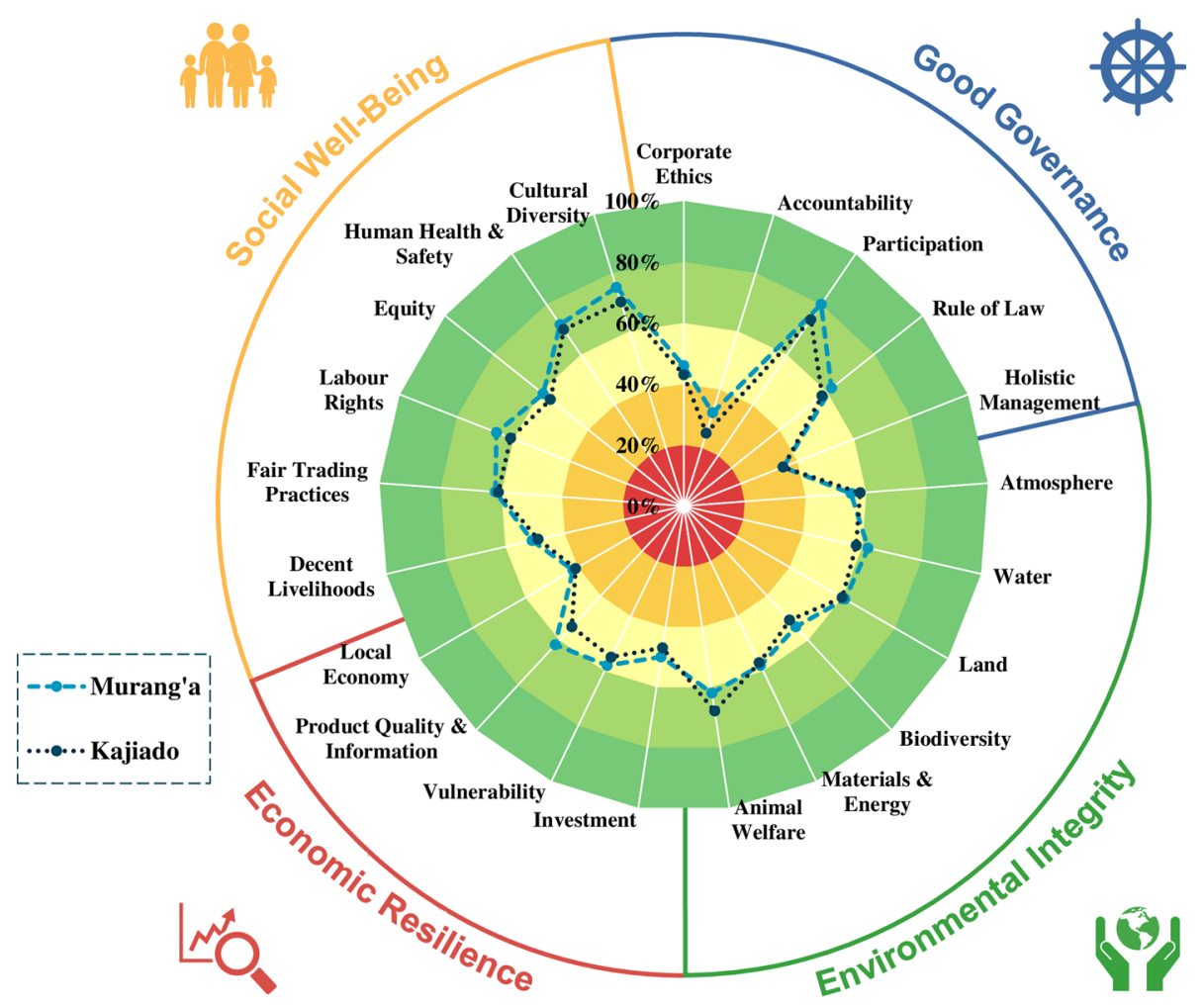

Fig. 2 Overall performance in degree of goal achievement (DGA) from the SMART-Farm Tool across four sustainability dimensions and 21 sustainability themes for 400 farms in Kajiado and Murang'a counties in Kenya 
Similarly, other SAFA-based studies found a poor performance in terms of Accountability and Holistic Management of smallholder farms in developing countries and elsewhere (Landert et al., 2017; Pérez-Lombardini et al., 2021; Schader et al., 2016). A study of noncertified and conventional smallholder coffee farmers in Ethiopia, for example, found that they did not use formal farm monitoring methods (Winter et al., 2020). Poor documentation (e.g. failure to keep records, inconsistent or scanty records, monitoring and evaluation) has been identified as a major challenge for smallholder farms in Kenya, and may limit the economic success of a farm (Muriithi et al., 2014).

The accounting, recording and monitoring of a farm's activities can be knowledge intensive, which is often a challenge especially given that majority of the farmers in this study have no formal education beyond high school with an average of nine years schooling (Kamau et al., 2018). In SSA, this has mainly been attributed to low literacy levels among smallholder farmers, particularly women as reported in South Africa and Kenya for instance (Gyau et al., 2016; Marandure et al., 2017). This gap in knowledge and skills in turn leads to low adoption of sustainable practices that are often knowledge intensive (D'Annolfo et al., 2021). In line with other studies in Kenya and beyond, we consider capacity building in bookkeeping as crucial to improve the sustainability performance of smallholder farms (Gyau et al., 2016; Kabubo-Mariara et al., 2009; Marandure et al., 2020). Although assessing the performance of a farms accountability is challenging in Kenya in terms of monitoring them through some sort of a sustainability reporting system, training farmers in documentation, even for those with limited formal education, can go a long way in increasing transparency and monitoring farm performance. In this aspect, smallholder certification schemes have shown success in improving farm record keeping, tracking and reporting (Kamau et al., 2018; Winter et al., 2020).

\subsubsection{Capacity development}

Capacity Development in the dimension of Social Well-Being (DGA $<22 \%$ ) was also relatively weak for smallholder farmers in the areas studied (Figs. 3d, 4d and 5d) due to limited training of farm workers, e.g. in the use of chemical farm products and access to advisory services (Appendix A, Table S1).

There is evidence that capacity development opportunities exist in both Kajiado and Murang'a, and are normally offered by state and non-state actors. However, limited coordination, inadequate technical and personnel capacities and resources remain a challenge for developing capacity (Davis \& Place, 2003; Rees et al., 2000). In addition, the gap in technical knowledge in farming as observed in this study in terms of poor handling of chemicals has been reported in various regions of Kenya, for instance with regard to technical information on pest and disease management, use of inputs and irrigation technology (Mati, 2008; Rees et al., 2000). Given that management of farm inputs and soil fertility can be a major barrier to the sustainability of smallholder farms (Grenz et al., 2009; Kamau et al., 2019), there is a need to fill knowledge and skill gaps among farmers and their employees. Better coordination and a stronger role of the national government in extension services without over-reliance on non-state actors have been argued to be imperative (Davis \& Place, 2003). In addition, other capacity building initiatives have been claimed to be successful in filling these gaps. For instance, demand-driven extension services (Ngigi et al., 2016) and farmer-to-farmer training approaches (Lukuyu et al., 2012). Strengthening human capacity is a precondition for improving the sustainability of rural livelihoods for communities that depend on rainfed agriculture as was found for example in Azerbaijan 
Fig. 3 Average performance in degree of goal achievement (DGA) from the SMART-Farm Tool of 400 farms in Kajiado and Murang'a counties in Kenya in relation to five farm types across 21 sustainability themes and 58 subthemes in the four dimensions of sustainability (*asterisk after subtheme title represents subthemes with significantly different sustainability performance)

(Aliloo \& Dashti, 2021). Despite the existence many avenues to build capacity in Africa including extension, informal education sources like radio, television and mobile phone, Africa's spending on agricultural research and development remains very low, at less than $7 \%$ of the gross domestic product, compared to other developing regions in Asia and Latin America (Asenso-Okyere, 2009).

\subsection{Comparison of farm sustainability performance with respect to farm types, counties and certification status}

In general, summary statistics on the average farm sustainability performance showed hardly any differences across the five farm types (Fig. 3a-d). However, slight differences were observed where farms in Murang' a performed better than those in Kajiado (Fig. 4a-d) and certified farms performed better than non-certified ones (Fig. 5a-d).

Our MANOVA model revealed no statistically significant differences in sustainability performance for the subthemes between the five farm types (Pillai's Trace $=0.7, F(232$, $1172)=1.10, p=0.16$ ), but significant differences between the two counties (Pillai's Trace $=0.7, F(58,290)=10.1, p<0.001)$. The interaction between farm types and counties was significant (Pillai's Trace $=0.8, F(232,1172)=1.23, p=0.02)$ due to a higher level of interaction in some subthemes, which was mainly induced by county differences, as sustainability performance among the five farms types did not differ significantly $(p>0.05)$ (Appendix A, Table S3). However, significant differences were found between certified and non-certified farms (Pillai's Trace $=0.4, F(58,296)=3.75, p<0.001$ ), the two counties (Pillai's Trace $=0.6, F(58,296)=8.57, p<0.001)$, and the interaction between farm certification and counties (Pillai's Trace $=0.3, F(58,296)=1.84, p<0.01$ ). The outcome of the multiple linear fixed-effects models reveals the effects of the factors for each subtheme (Table 2, Appendix A and B).

Since no major differences in the sustainability performance of the five farm types were found, we do not discuss these results further. For a summary of high-impact indicators that contributed to significant differences (from results of the GLM models) in subtheme scores with respect to certification status, farm type and county (see Tables 3, 4 and 5). In Appendix B, the indicators influencing these results are described in relation to the themes and subthemes and the objectives of the SAFA Guidelines.

\subsection{Indicators responsible for differences in the sustainability performance of farms}

\subsubsection{Differences in land and crop management practices of certified and non-certified farms}

The main factor differentiating organically certified farms from non-certified farms was management and use of harmful chemicals (Table 3). Agrochemicals and fertilizers were not used on certified organic farms. Certified farms also performed more soil tests 

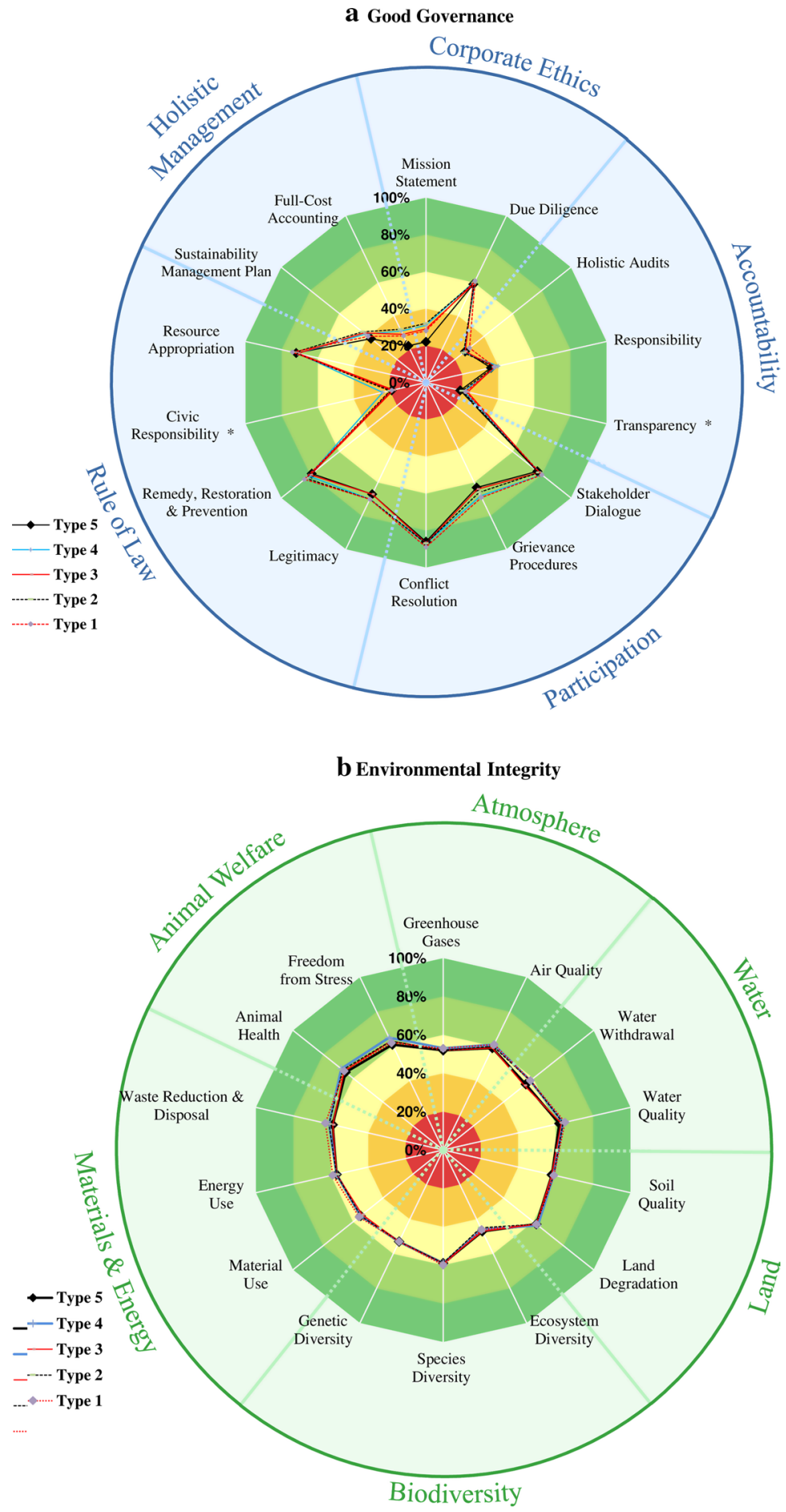

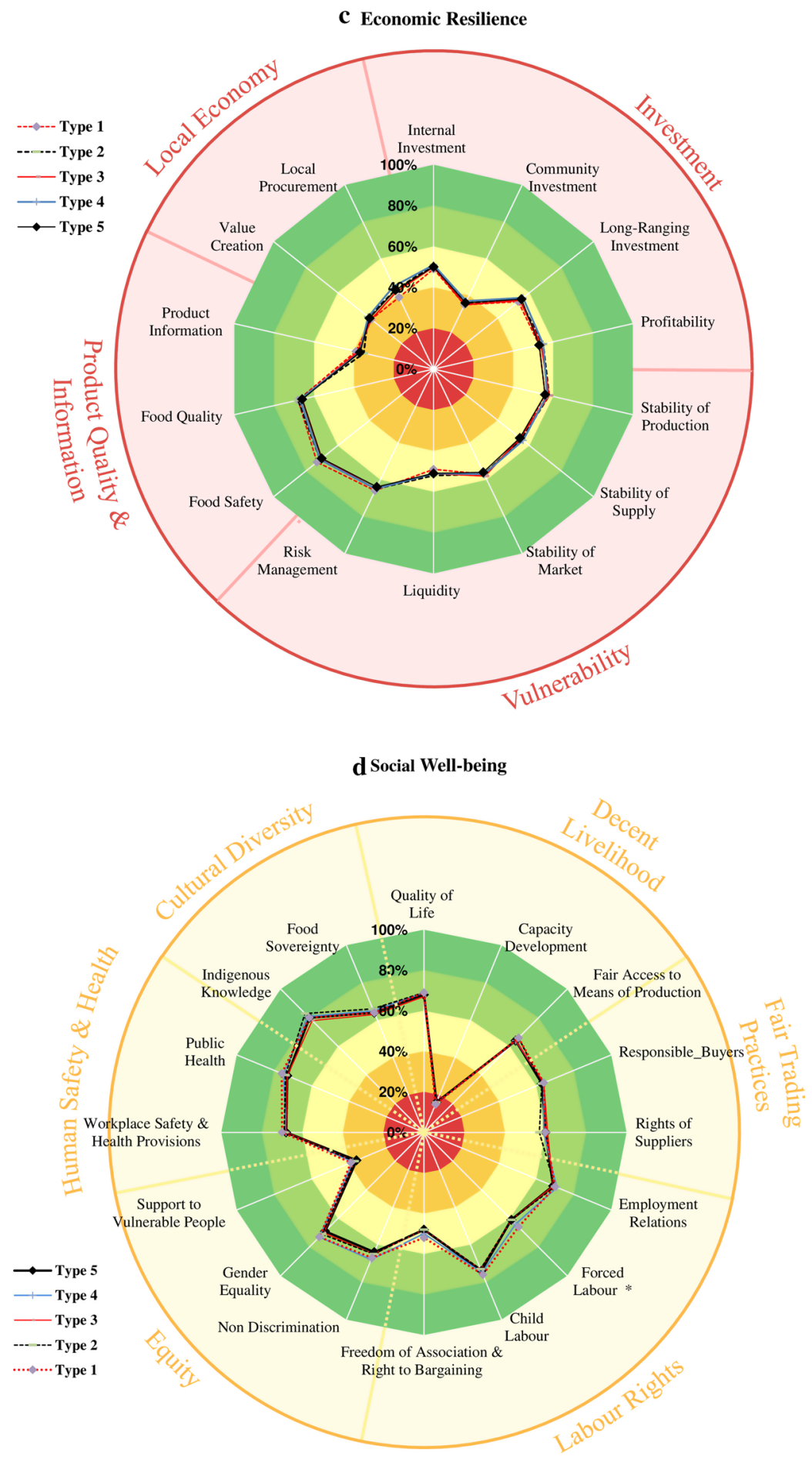

Fig. 3 (continued) 
to determine fertilizer requirements and were less likely to apply manure from livestock treated with antibiotics on cultivated areas, and there were more agroforestry systems in certified than in non-certified farms (Table 3), which led to improved performance in subthemes related to biodiversity and soil quality (Table 4). However, the differences between certified and non-certified farms were not significant in terms of recycling of crop residues, use of compost and farmyard manure, number of perennial crops, yield level, share of legumes on arable land, and share of degraded land (Table 3). The findings imply that the soil management practices of organic farmers therefore do not differentiate them from their non-certified counterparts and they are comparable in terms of soil depletion and yields. However, certified farms were found to enhance agrobiodiversity by avoiding the use harmful synthetic chemicals. This finding is important for Kenya where over 12 million people live on degraded land and degradation of arable land is an ongoing problem (Mulinge et al., 2016).

In terms of soil management practices, these findings are similar to those of previous studies on the sustainability of certified and non-certified organic smallholder farms in Africa. For instance, there was no major difference in the application of 'good' production practices related to soil, pest and disease management between certified and non-certified farms growing coffee in Uganda (Ssebunya et al., 2019). In Ethiopia, expert assessments of smallholder coffee farms concluded that certified farms did not differ from their non-certified counterparts because they were all extensive low external input systems (Winter et al., 2020). In a long-term system comparison of high- and low-input organic and conventional systems in Kenya, results indicated that low-input systems, including organic systems, lead to resource depletion over a long period of time (Adamtey et al., 2016) and could undermine benefits associated with OA.

Nevertheless, the results of this and other studies show the potential of OA to increase biodiversity and improve soil and water quality (Kamau et al., 2019; Muller et al., 2017). For instance, in an earlier independent in-depth assessment of soil fertility and arthropod biodiversity in a subset of the farms used in the current study $(n=20)$, it was found that biodiversity was significantly higher in certified organic farms compared to their non-certified or non-organic counterparts, but soil fertility was not significantly different (Kamau et al., 2019). In Colombia, a farm-level sustainability assessment found better environmental practices particularly less use of agrochemicals among organic certified farms (Furumo et al., 2020). In a long-term organic and conventional comparison trial in Kenya, there was a higher termite abundance, activity and diversity in organic systems compared to conventional systems (Anyango et al., 2020). Recent evidence from reviews of literature on agricultural sustainability reiterate that agrochemicals negatively affect soil health; these studies indicate the need to increase agrobiodiversity in farms to make them more resilient to climate change and other shocks (El Chami et al., 2020).

\subsubsection{Differences in land and crop management practices on Kajiado and Murang'a farms}

There was a poorer sustainability performance of the farms in the drier ASAL Kajiado County compared to the more humid Murang'a County in terms of land and crop management practices. In Kajiado, there were fewer activities to improve soil humus, a lower number of scattered fruit trees and perennial crops as well as limited soil improving or degradation mitigation measures (Table 5 and Appendix A, Table S6). 
Fig. 4 Average performance in degree of goal achievement (DGA) from the SMART-Farm Tool of 400 farms in Kajiado and Murang'a counties in Kenya in relation to the two counties across 21 sustainability themes and 58 subthemes in the four dimensions of sustainability (*asterisk after subtheme title represents subthemes with significantly different sustainability performance)

Similarly, low uptake and use of soil conserving cultivation practices have been reported in other ASAL regions of Kenya due to limited access to productive assets including land, inputs and markets (Mutuku et al., 2017). This can be exacerbated by water scarcity and erratic weather (Njiru, 2012). Despite their associated benefits, the cultivation of perennial crops and fruit trees on small-scale farms in East and Central Africa is constrained by a lack of improved varieties and markets (Jama et al., 2008). Adverse effects of climate change pose other threats like yield reduction in key crops if adaptation measures are not taken (Njiru, 2012; Spaling et al., 2011). The increased use of practices that conserve resources is crucial for farm sustainability, as agronomic practices affect soil fertility and productivity (Adamtey et al., 2016). Improved access to productive assets has the potential to enhance the adoption of these practices.

\subsubsection{Farm enterprises}

Our results reveal that the economic resilience of certified organic farms was enhanced by more long-term investments in farm infrastructure and land, and more diversified sales and income sources, but was reduced by higher yield losses compared to non-certified farms (Table 5 and Appendix A, Table S4, S5).

Organic agriculture is usually associated with production diversification e.g. in crops through intercropping and crop rotation, which reduces vulnerability to different economic and environmental shocks (Pérez-Lombardini et al., 2021; Singh \& Maharjan, 2017). In general, diversification is positively associated with risk reduction and wealth accumulation (Barrett et al., 2001; Davis et al., 2017), but these benefits can be undermined by yield losses, which can affect farm income and consequently, economic resilience. Investment in farms could allow them to develop into commercially viable business enterprises, which could contribute to better economic sustainability (Davis et al., 2017), and diversification can play an important role.

For the counties in this study, the higher economic sustainability in Murang'a compared to Kajiado was a result of the higher commercial farm viability, longer customer relationships, and lower product returns from customers. However, lower levels of credit access and less awareness of future market challenges reduced the economic sustainability of those farms (Tables 4, 5 and Appendix A, Tables S4, S5).

Previous evidence from Murang'a supports our findings of limited market knowledge and involvement by farmers in agricultural value chains and agricultural markets that are poorly developed despite high agricultural potential (Ekbom et al., 2001). Due to locally poor credit markets, there is also low credit uptake in Murang'a even for farmers with land title deeds that can be used as collateral (Gyau et al., 2016; Ndukhu et al., 2016). Despite Kenya's relatively advanced banking sector, banks often view farming as a highly risky field to invest in. However, access to agricultural financing is vital for pro-poor growth (Place, 2009). There is a need to provide sound loan products to finance agriculture by removing barriers to both lenders and borrowers. One way, especially for asset-poor farmers, is through group-based access (Ngigi et al., 2016). Furthermore, collective action has been put forward as a strategy to improve farmers' involvement in agricultural value chains 


\section{a Good Governance}

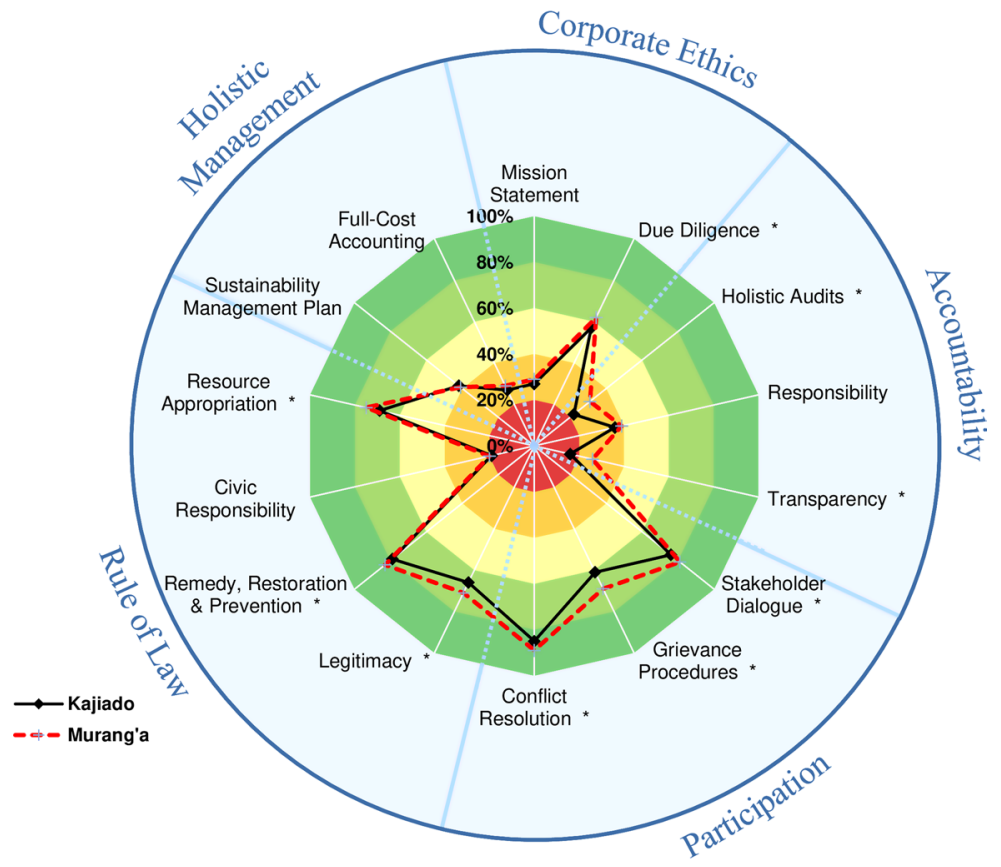

b Environmental Integrity

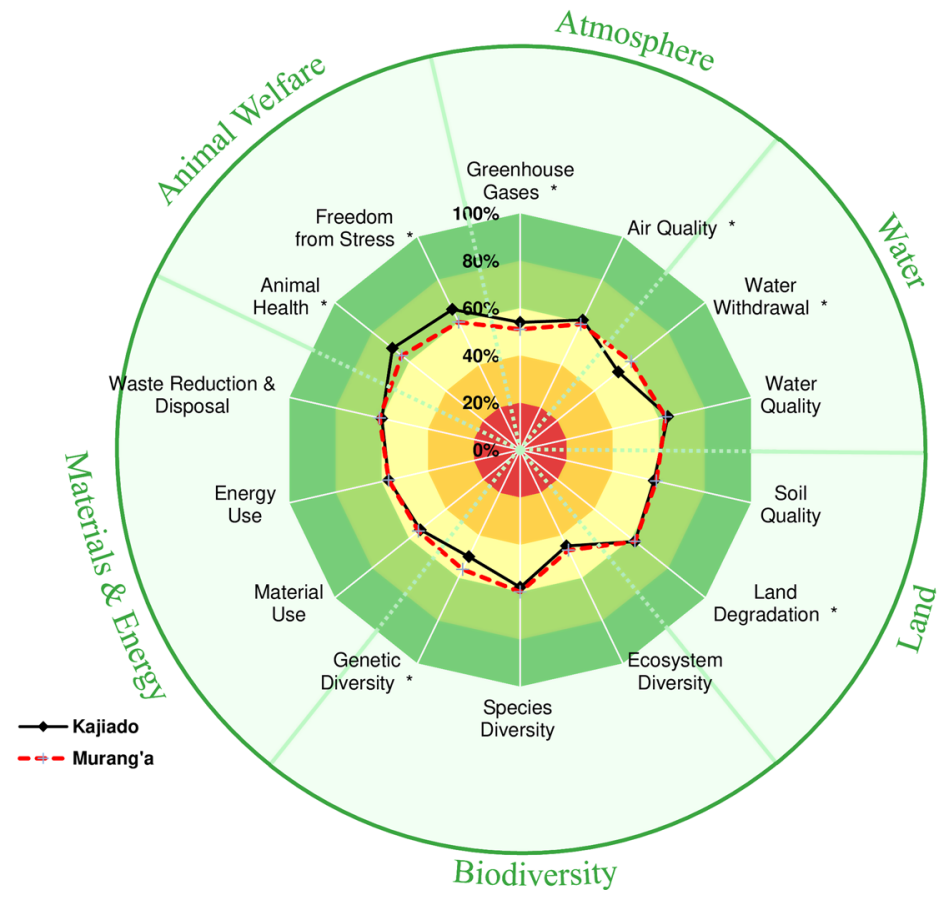



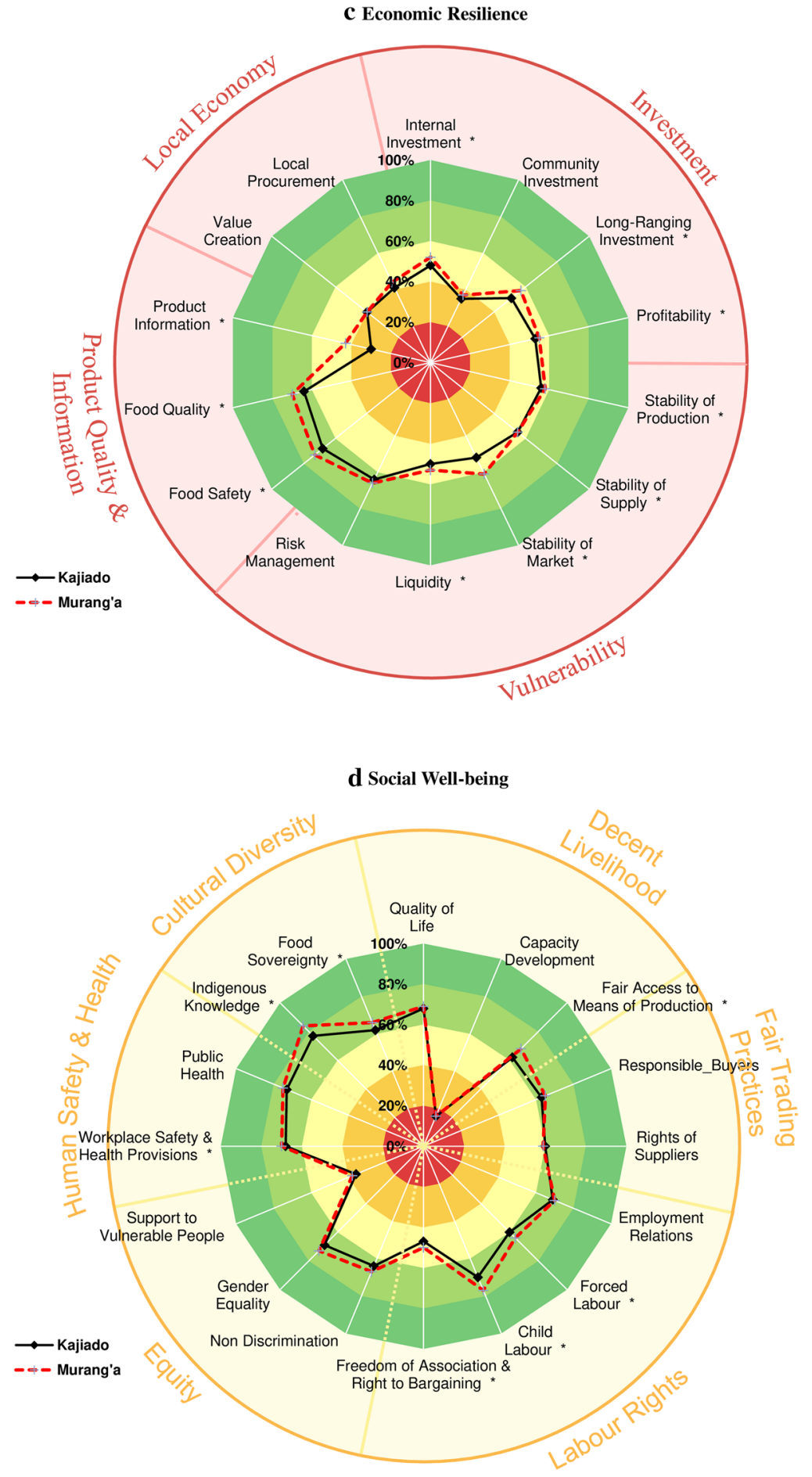

Fig. 4 (continued) 
(Gyau et al., 2016). Agricultural insurance is also emerging in SSA as a safety net to protect farmers against climatic and other shocks. For instance, loans and farm inputs can be bundled with other insurance services, thereby shielding both lenders and borrowers (Nshakira-Rukundo et al., 2021).

\subsubsection{Farmer and employee welfare}

Our results reveal that certified organic farms provided greater support for disadvantaged groups, had more permanently employed workers and workers with social protection than non-certified farms, although the proportion of these workers was very low in both cases. In addition, farms in Kajiado had better support for the disadvantaged although these workers still had poorer access to health care than those on farms in Murang'a (Table 4).

The limited social security in Kenyan smallholder farming observed in the current study (Table 4) was also noted by others (Grenz et al., 2009). Terms of employment are important in determining the level of support to workers. Informal wage workers, who are mostly women and the youth (i.e. below 35 years), make up $>60 \%$ of the labour force in rural Kenya, and are largely affected by unemployment, little or no social security, low wages and lack of essential employment rights (Dolan, 2004; Keizi, 2006). Kenya has a national safety net program that targets poor and vulnerable people, those with severe disabilities, older persons, and children (World Bank, 2013). However, poor institutional coordination and management, as well as limited awareness among workers hinders the success of these programs (ILO, 2016; Mathauer et al., 2008). Therefore, stronger linkages between institutions involved in social protection and empowerment of workers have the potential to improve this situation. Moreover, addressing social protection for farm workers as well as tax incentives to induce savings by low-income groups, could enhance workers involvement in the national programmes for medical care and retirement benefits that already exist in Kenya (Dolan, 2004; Keizi, 2006). Agricultural intensification in SSA could increase demand for labour saving technologies (Dahlin \& Rusinamhodzi, 2019), which could reduce the already few employment opportunities available in this region. Since agriculture will remain the main source of livelihood in Kenya and other SSA countries in the near future, it is important to improve terms of employment, social protection programmes, and investments in creating opportunities along the agricultural value chain beyond production. This could provide more and better job opportunities and working conditions for the agricultural workforce in Kenya and beyond.

\subsubsection{Animal husbandry}

Animal welfare, in terms of health and freedom from stress, did not vary significantly between certified and non-certified organic farms (Table 2). However, major differences in animal husbandry practices between counties were observed. In Murang'a, low performance for animal welfare was due to a lack of clean and animal-friendly housing, limited drinking points and outdoor access, lack of quarantine areas, limited access to pasture, and poor animal slaughter standards. In addition, Murang' a farms had more uncovered slurry stores.

These regional differences have been documented before. For instance, studies in Murang'a found that animals were rarely let loose and were mainly confined to their designated housing or tethered. This was attributed to years of land fragmentation and rapid population growth resulting in small land holdings (Ekbom et al., 2001; Ovuka, 2000) 
Fig. 5 Average performance in degree of goal achievement (DGA) from the SMART-Farm Tool of 400 farms in Kajiado and Murang'a counties in Kenya in relation to farm certification status across 21 sustainability themes and 58 subthemes in the four dimensions of sustainability (*asterisk after subtheme title represents subthemes with significantly different sustainability performance)

unlike in Kajiado, where average landholdings are larger and outdoor animal movement is less restricted (Odhong et al., 2014). Poor-quality livestock shelters in Murang'a lead to poor air quality, parasites, infections, dust and mould (Lekasi et al., 2003). Although Kenya has a comprehensive legal animal welfare framework (Masiga \& Munyua, 2005), the findings of our study suggest that there is an urgent need to improve animal welfare through better livestock management practices, especially in densely populated humid regions like Murang'a. In addition, the uncovered slurry in the county contributes to anthropogenic greenhouse gas emissions such as nitrous oxide and methane (Mgbenka, 2013), and this suggests a general need to improve animal husbandry practices on farms in Murang'a.

In Kajiado, farms reared far fewer hybrid livestock compared to those in Murang'a (Table 5). Limited rearing of hybrid livestock in Kajiado and other ASAL regions in Kenya has been attributed to preferences for local breeds that are less vulnerable to those environmental stresses more prevalent in ASAL regions, although these local breeds are argued to have lower productivity (Otieno, 2012). In general, agrobiodiversity reduces vulnerability to pests and diseases as well as to other environmental stressors like drought (Altieri, 2009; Di Falco \& Chavas, 2006). In making choices about herd diversity, farmers must consider trade-offs in productivity and lasting resilience.

\subsubsection{Land-use conflicts and investment}

Our results indicate differences in the availability and implementation of mechanisms to prevent resource use conflicts. Conflicts were higher where farm ownership was unclear or disputed (i.e. in Kajiado) compared to areas where more secure land-tenure rights exist (i.e. in Murang'a) (Table 5).

There is evidence of land-use conflicts in Kajiado associated with resource competition between herding, crop cultivation and wildlife. These conflicts are largely the result of regional effects of demographic pressure, land subdivision and climate change on agriculture (Campbell et al., 2000; Njiru, 2012; Ogutu et al., 2014). Land ownership in Kajiado is gradually transforming from communal ownership to privatization and individual ownership as people immigrate from more densely populated areas, driving conflicts in the use of land (Campbell et al., 2000; Kabubo-Mariara et al., 2009). Although our study did not determine an association between conflict and land tenure, malfunctioning land tenure in Kajiado has been found to be associated with resource-use conflicts (Campbell et al., 2000; Ogutu et al., 2014). In Murang'a, however, land rights are overall more secure and based on family and clan affiliation systems, where common resources like woodlands, grazing land and water resources are clearly demarcated and less disputed (Ekbom et al., 2001; Mackenzie, 1989).

Land-tenure insecurity could partly explain the limited long-term investments in soil improvement on the farms in Kajiado (Table 5). Land-tenure insecurity considerably advances food insecurity and poverty in SSA (Radwan, 1995; Salami et al., 2010). Secure land tenure can help in reducing poverty (Radwan, 1995). It can also lead to lasting investments in land conservation (Gebremedhin \& Scott, 2003; Shepherd \& Soule, 1998), as 

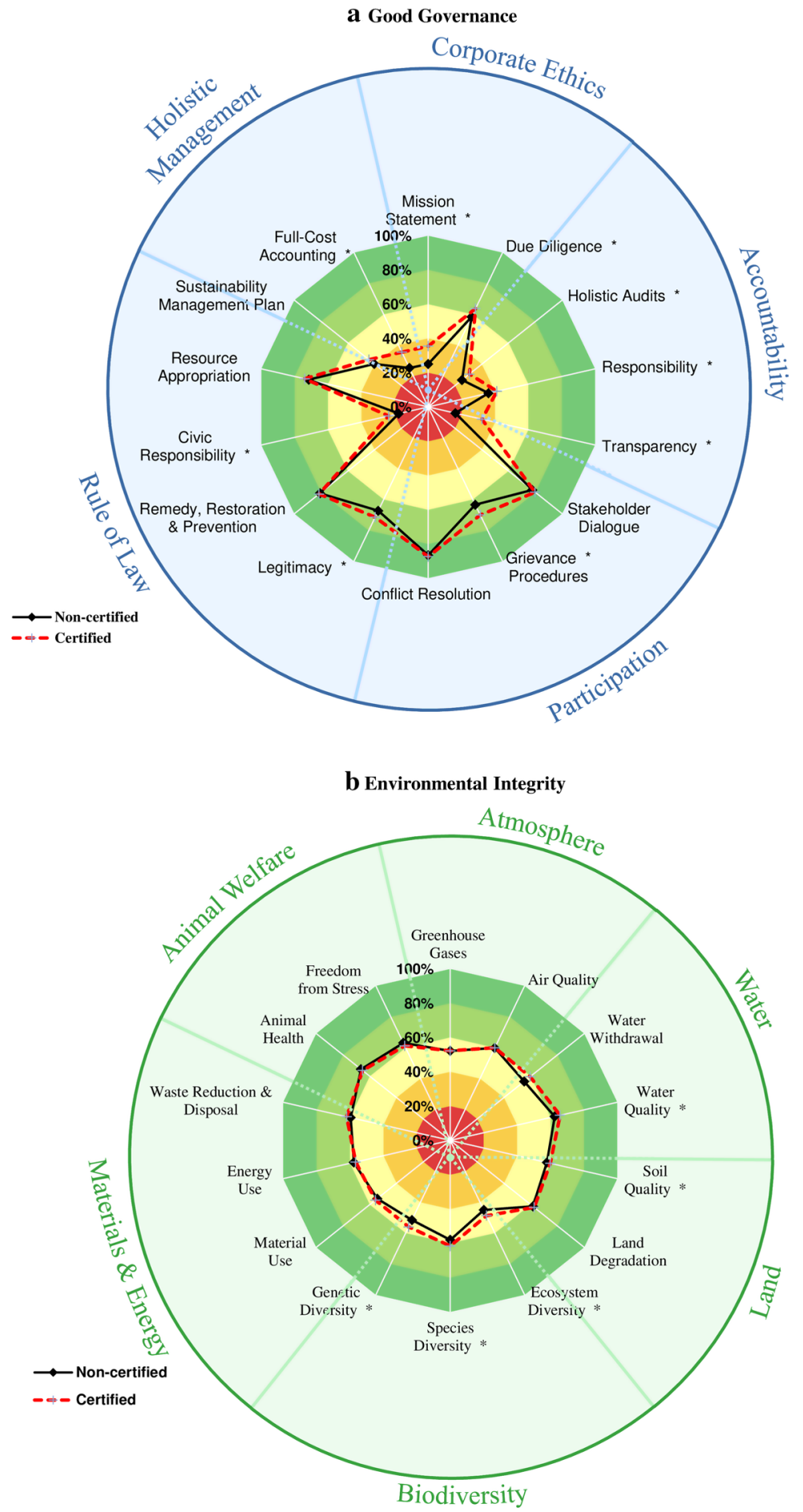


\section{c Economic Resilience}

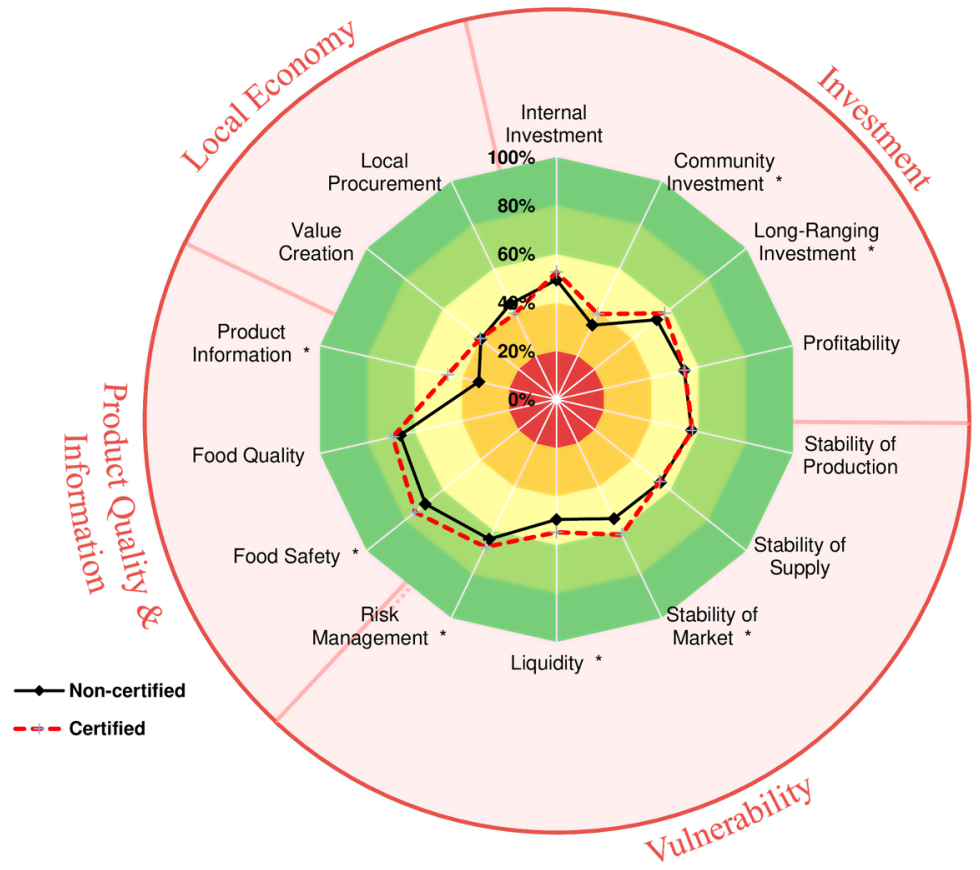

d Social Well-being

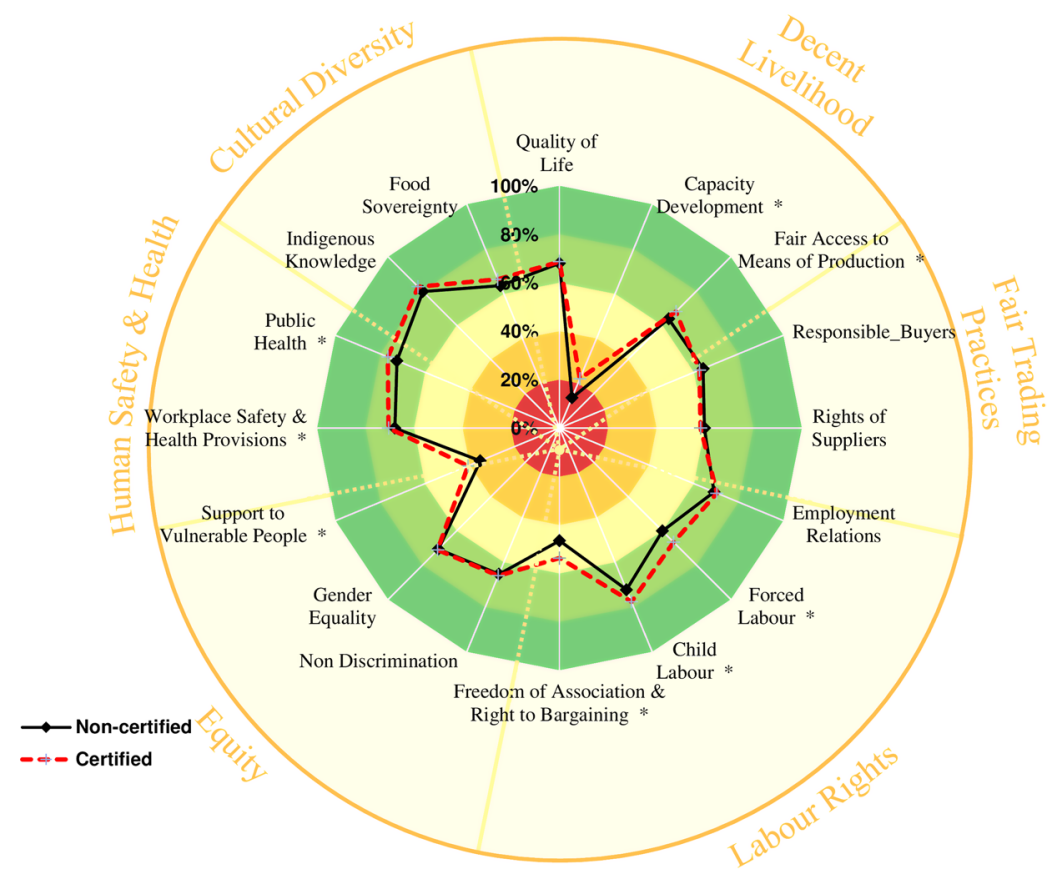

Fig. 5 (continued) 
Table 2 Mean values of the degree of goal achievement (DGA) from the SMART-farm * tool for each subtheme by certification status and county for 400 farms in Kenya

\begin{tabular}{|c|c|c|c|c|c|c|c|c|c|c|c|}
\hline \multirow[b]{2}{*}{ Subtheme } & \multicolumn{3}{|c|}{ Certification Status } & \multirow[b]{2}{*}{$p$} & \multicolumn{2}{|l|}{ County } & \multicolumn{5}{|c|}{ Certification Status and County } \\
\hline & $p$ & $\begin{array}{l}\text { Certi } \\
\text { fied }\end{array}$ & $\begin{array}{l}\text { Non- } \\
\text { certif } \\
\text { ied }\end{array}$ & & $\begin{array}{l}\text { Murang } \\
\text { 'a }\end{array}$ & $\begin{array}{l}\text { Kaji } \\
\text { ado }\end{array}$ & $p$ & $\begin{array}{l}\text { Certifi } \\
\text { ed } \times \\
\text { Muran } \\
\text { g'a }\end{array}$ & $\begin{array}{l}\text { Certifi } \\
\text { ed } \times \\
\text { Kajiad } \\
\text { o }\end{array}$ & $\begin{array}{l}\text { Non- } \\
\text { certifie } \\
\text { d } \\
\times \\
\text { Muran } \\
\text { g'a }\end{array}$ & $\begin{array}{l}\text { Non- } \\
\text { certifi } \\
\text { ed } \times \\
\text { Kajiad } \\
\text { o } \\
\end{array}$ \\
\hline $\begin{array}{l}\text { Mission } \\
\text { Statement }\end{array}$ & $\begin{array}{l}p<0 \\
05\end{array}$ & $35.7 \mathrm{a}$ & $27.1 \mathrm{~b}$ & ns & $30.6 \mathrm{a}$ & $\begin{array}{l}32.2 \\
\mathrm{a}\end{array}$ & ns & $34.1 \mathrm{a}$ & $37.2 \mathrm{a}$ & $27 \mathrm{a}$ & $27.3 \mathrm{a}$ \\
\hline $\begin{array}{l}\text { Due } \\
\text { Diligence }\end{array}$ & $\begin{array}{l}p<0 \\
001\end{array}$ & $64.1 \mathrm{a}$ & $59.2 \mathrm{~b}$ & ns & $62.7 \mathrm{a}$ & $\begin{array}{l}60.7 \\
a\end{array}$ & $\begin{array}{l}p<0 . \\
01\end{array}$ & $63.3 \mathrm{a}$ & $64.9 \mathrm{a}$ & $62.1 \mathrm{a}$ & $56.4 \mathrm{~b}$ \\
\hline $\begin{array}{l}\text { Holistic } \\
\text { Audits }\end{array}$ & $\begin{array}{l}p<0 \\
05\end{array}$ & $31.8 \mathrm{a}$ & $27.1 \mathrm{~b}$ & $\begin{array}{l}p<0 \\
05\end{array}$ & $31.6 \mathrm{a}$ & $\begin{array}{l}27.3 \\
b\end{array}$ & $\begin{array}{l}p<0 \\
001\end{array}$ & $29.7 \mathrm{a}$ & $33.9 \mathrm{a}$ & $33.5 \mathrm{a}$ & $20.6 b$ \\
\hline $\begin{array}{l}\text { Responsibilit } \\
\mathrm{y}\end{array}$ & $\begin{array}{l}p<0 \\
01\end{array}$ & $42.5 \mathrm{a}$ & $36.8 \mathrm{~b}$ & ns & $39.1 \mathrm{a}$ & $\begin{array}{l}40.2 \\
\mathrm{a}\end{array}$ & $\begin{array}{l}\mathrm{p}<0 . \\
01\end{array}$ & $39 a$ & 45.9 & $39.3 \mathrm{a}$ & $34.4 \mathrm{~b}$ \\
\hline Transparency & $\begin{array}{l}p<0 \\
001\end{array}$ & $31.1 \mathrm{a}$ & $17.2 \mathrm{~b}$ & $\begin{array}{l}p<0 \\
001\end{array}$ & $27.9 \mathrm{a}$ & $\begin{array}{l}20.5 \\
b\end{array}$ & ns & $34.5 \mathrm{a}$ & $27.7 b$ & $21.2 \mathrm{a}$ & $13.2 \mathrm{~b}$ \\
\hline $\begin{array}{l}\text { Stakeholder } \\
\text { Dialogue }\end{array}$ & ns & $80.7 \mathrm{a}$ & $78.1 \mathrm{a}$ & ns & $80.4 \mathrm{a}$ & $\begin{array}{l}78.4 \\
a\end{array}$ & $\begin{array}{l}p<0 . \\
01\end{array}$ & $79.3 \mathrm{a}$ & $82 \mathrm{a}$ & $81.4 \mathrm{a}$ & $74.8 \mathrm{~b}$ \\
\hline $\begin{array}{l}\text { Grievance } \\
\text { Procedures }\end{array}$ & $\begin{array}{l}p<0 \\
001\end{array}$ & $69.4 \mathrm{a}$ & $63.5 b$ & $\begin{array}{l}p<0 \\
001\end{array}$ & $69.6 \mathrm{a}$ & $\begin{array}{l}63.3 \\
b\end{array}$ & ns & $70.9 \mathrm{a}$ & $67.9 \mathrm{a}$ & $68.3 \mathrm{a}$ & $58.8 \mathrm{~b}$ \\
\hline $\begin{array}{l}\text { Conflict } \\
\text { Resolution }\end{array}$ & ns & $87.8 \mathrm{a}$ & $86.8 \mathrm{a}$ & ns & $88.5 \mathrm{a}$ & $\begin{array}{l}86.2 \\
a\end{array}$ & $\begin{array}{l}p<0 . \\
05\end{array}$ & $86.9 \mathrm{ab}$ & $88.8 \mathrm{~b}$ & $90.1 \mathrm{~b}$ & $83.6 \mathrm{a}$ \\
\hline Legitimacy & $\begin{array}{l}p<0 \\
01\end{array}$ & $71.3 \mathrm{a}$ & $67.8 \mathrm{~b}$ & $\begin{array}{l}p<0 \\
01\end{array}$ & $71.6 \mathrm{a}$ & $\begin{array}{l}67.5 \\
b\end{array}$ & ns & $72.7 \mathrm{a}$ & $69.9 \mathrm{a}$ & $70.5 \mathrm{a}$ & $65.1 \mathrm{~b}$ \\
\hline $\begin{array}{l}\text { Remedy, } \\
\text { Restoration \& } \\
\text { Prevention }\end{array}$ & ns & $81.3 \mathrm{a}$ & $81.5 \mathrm{a}$ & ns & $82.7 \mathrm{a}$ & $\begin{array}{l}80.1 \\
\mathrm{a}\end{array}$ & ns & $81.4 \mathrm{ab}$ & $81.3 \mathrm{ab}$ & $84.1 b$ & $78.8 \mathrm{a}$ \\
\hline $\begin{array}{l}\text { Civic } \\
\text { Responsibilit } \\
\text { y }\end{array}$ & $\begin{array}{l}p<0 \\
01\end{array}$ & $26.4 \mathrm{a}$ & $18.2 \mathrm{~b}$ & ns & $20.3 \mathrm{a}$ & $\begin{array}{l}24.2 \\
\mathrm{a}\end{array}$ & $\begin{array}{c}p<0 \\
01\end{array}$ & $19.9 \mathrm{a}$ & 32.8 & $20.8 \mathrm{a}$ & $15.7 \mathrm{a}$ \\
\hline $\begin{array}{l}\text { Resource } \\
\text { Appropriation }\end{array}$ & ns & $74 a$ & $72 \mathrm{a}$ & $\begin{array}{l}p<0 . \\
01\end{array}$ & $75 \mathrm{a}$ & $71 b$ & $\begin{array}{l}p<0 \\
01\end{array}$ & $73.8 \mathrm{a}$ & $74.1 \mathrm{a}$ & $76.2 \mathrm{a}$ & $67.8 \mathrm{~b}$ \\
\hline $\begin{array}{l}\text { Sustainability } \\
\text { Management } \\
\text { Plan }\end{array}$ & ns & $44.8 \mathrm{a}$ & $41.1 \mathrm{a}$ & ns & $41.6 \mathrm{a}$ & $\begin{array}{l}44.3 \\
\mathrm{a}\end{array}$ & ns & $41.2 \mathrm{a}$ & $48.4 \mathrm{a}$ & $42.1 \mathrm{a}$ & $40.2 \mathrm{a}$ \\
\hline $\begin{array}{l}\text { Full-Cost } \\
\text { Accounting }\end{array}$ & $\begin{array}{l}p<0 \\
05\end{array}$ & $35.7 \mathrm{a}$ & $27.3 b$ & ns & $30.6 \mathrm{a}$ & $\begin{array}{l}32.4 \\
\mathrm{a}\end{array}$ & ns & $34.1 \mathrm{a}$ & $37.3 \mathrm{a}$ & $27.1 \mathrm{a}$ & $27.5 \mathrm{a}$ \\
\hline $\begin{array}{l}\text { Greenhouse } \\
\text { Gases }\end{array}$ & ns & $53.2 \mathrm{a}$ & $52.6 \mathrm{a}$ & $\begin{array}{l}p<0 \\
001\end{array}$ & $51 \mathrm{a}$ & $\begin{array}{l}54.8 \\
\mathrm{~b}\end{array}$ & ns & $51.1 \mathrm{a}$ & $55.3 \mathrm{~b}$ & $50.9 \mathrm{a}$ & $54.3 \mathrm{~b}$ \\
\hline Air Quality & ns & $60.8 \mathrm{a}$ & $60.2 \mathrm{a}$ & $\begin{array}{l}p<0 \\
001\end{array}$ & $59 \mathrm{a}$ & $\begin{array}{l}61.9 \\
b\end{array}$ & ns & $59.2 \mathrm{a}$ & $62.4 \mathrm{~b}$ & $58.9 \mathrm{a}$ & $61.4 \mathrm{~b}$ \\
\hline $\begin{array}{l}\text { Water } \\
\text { Withdrawal }\end{array}$ & ns & $58.7 \mathrm{a}$ & $56.3 \mathrm{a}$ & $\begin{array}{l}p<0 . \\
001\end{array}$ & $60.4 \mathrm{a}$ & $\begin{array}{l}54.5 \\
\mathrm{~b}\end{array}$ & ns & $61.1 \mathrm{c}$ & $56.3 \mathrm{ab}$ & $59.8 \mathrm{bc}$ & $52.8 \mathrm{a}$ \\
\hline Water Quality & $\begin{array}{l}p<0 \\
01\end{array}$ & $66.1 \mathrm{a}$ & $63.2 \mathrm{~b}$ & ns & $64 a$ & $\begin{array}{l}65.4 \\
a\end{array}$ & ns & $65.9 \mathrm{a}$ & $66.4 \mathrm{a}$ & $62.1 \mathrm{~b}$ & $64.4 \mathrm{a}$ \\
\hline Soil Quality & $\begin{array}{l}p<0 . \\
05\end{array}$ & $60.2 \mathrm{a}$ & $58.4 \mathrm{~b}$ & ns & $59.3 \mathrm{a}$ & $\begin{array}{l}59.3 \\
\mathrm{a}\end{array}$ & ns & $60.2 \mathrm{~b}$ & $60.1 \mathrm{ab}$ & $58.4 \mathrm{a}$ & $58.4 \mathrm{a}$ \\
\hline $\begin{array}{l}\text { Land } \\
\text { Degradation }\end{array}$ & ns & $63 a$ & $62.1 \mathrm{a}$ & $\begin{array}{l}p<0 . \\
05\end{array}$ & $61.9 \mathrm{a}$ & $\begin{array}{l}63.1 \\
b\end{array}$ & ns & $62.2 \mathrm{ab}$ & $63.7 \mathrm{~b}$ & $61.6 \mathrm{a}$ & $62.5 \mathrm{ab}$ \\
\hline $\begin{array}{l}\text { Ecosystem } \\
\text { Diversity }\end{array}$ & $\begin{array}{l}p<0 \\
01\end{array}$ & $49.1 \mathrm{a}$ & $46 \mathrm{~b}$ & ns & $47.6 \mathrm{a}$ & $\begin{array}{l}47.5 \\
\mathrm{a}\end{array}$ & ns & $48.9 c$ & $49.4 b c$ & $46.4 \mathrm{ab}$ & $45.6 \mathrm{a}$ \\
\hline $\begin{array}{l}\text { Species } \\
\text { Diversity }\end{array}$ & $\begin{array}{l}p<0 \\
001\end{array}$ & $62.1 \mathrm{a}$ & $58.8 \mathrm{~b}$ & ns & $60.4 \mathrm{a}$ & $\begin{array}{l}60.6 \\
a\end{array}$ & ns & $61.6 \mathrm{~b}$ & $62.7 \mathrm{~b}$ & $59.1 \mathrm{a}$ & $58.5 \mathrm{a}$ \\
\hline $\begin{array}{l}\text { Genetic } \\
\text { Diversity }\end{array}$ & $\begin{array}{l}p<0 \\
001\end{array}$ & $56.1 \mathrm{a}$ & $52.6 \mathrm{~b}$ & $\begin{array}{l}p<0 \\
01\end{array}$ & $55.9 \mathrm{a}$ & $\begin{array}{l}52.8 \\
\mathrm{~b}\end{array}$ & $\begin{array}{l}p<0 . \\
05\end{array}$ & $56.5 \mathrm{a}$ & $55.8 \mathrm{a}$ & $55.4 \mathrm{a}$ & $49.8 b$ \\
\hline Material Use & ns & $56.4 \mathrm{a}$ & $55.2 \mathrm{a}$ & ns & $55.8 \mathrm{a}$ & $\begin{array}{l}55.8 \\
\mathrm{a}\end{array}$ & ns & $56.5 \mathrm{a}$ & $56.2 \mathrm{a}$ & $55 \mathrm{a}$ & $55.4 \mathrm{a}$ \\
\hline Energy Use & ns & $57.3 \mathrm{a}$ & $58.2 \mathrm{a}$ & ns & $57.5 \mathrm{a}$ & $58 \mathrm{a}$ & $\mathrm{ns}$ & $56.8 \mathrm{a}$ & $57.7 \mathrm{a}$ & $58.2 \mathrm{a}$ & $58.3 \mathrm{a}$ \\
\hline $\begin{array}{l}\text { Waste } \\
\text { Reduction \& } \\
\text { Disposal }\end{array}$ & ns & $62.4 \mathrm{a}$ & $60.4 \mathrm{a}$ & $\mathrm{ns}$ & $61.4 \mathrm{a}$ & $\begin{array}{l}61.3 \\
\mathrm{a}\end{array}$ & ns & $63.3 \mathrm{~b}$ & $61.5 \mathrm{ab}$ & $59.6 \mathrm{a}$ & $61.2 \mathrm{ab}$ \\
\hline $\begin{array}{l}\text { Animal } \\
\text { Health }\end{array}$ & ns & $67.1 \mathrm{a}$ & $66.7 \mathrm{a}$ & $\begin{array}{l}p<0 . \\
001\end{array}$ & $63.8 \mathrm{a}$ & $70 \mathrm{~b}$ & ns & $62.9 a$ & $71.3 \mathrm{~b}$ & $64.7 \mathrm{a}$ & $68.6 \mathrm{~b}$ \\
\hline
\end{tabular}


Table 2 (continued)

\begin{tabular}{|c|c|c|c|c|c|c|c|c|c|c|c|}
\hline $\begin{array}{l}\text { Internal } \\
\text { Investment }\end{array}$ & ns & $52.4 \mathrm{a}$ & $50.5 \mathrm{a}$ & $\begin{array}{l}p<0 \\
05\end{array}$ & $52.7 \mathrm{a}$ & $\begin{array}{l}50.2 \\
b\end{array}$ & ns & $53.4 \mathrm{~b}$ & $51.5 \mathrm{ab}$ & $52 b$ & $48.9 a$ \\
\hline $\begin{array}{l}\text { Community } \\
\text { Investment }\end{array}$ & $\begin{array}{l}p<0 . \\
001\end{array}$ & $39.8 \mathrm{a}$ & $34.7 b$ & $\mathrm{~ns}$ & $37.1 \mathrm{a}$ & $\begin{array}{l}37.4 \\
\mathrm{a}\end{array}$ & $\begin{array}{l}p<0 \\
05\end{array}$ & $38.1 \mathrm{bc}$ & $41.5 \mathrm{c}$ & $36 a b$ & $33.3 \mathrm{a}$ \\
\hline $\begin{array}{l}\text { Long-term } \\
\text { Investment }\end{array}$ & $\begin{array}{l}p<0 . \\
05\end{array}$ & $57.5 \mathrm{a}$ & $54.2 b$ & $\begin{array}{l}p<0 \\
05\end{array}$ & $57.2 \mathrm{a}$ & $\begin{array}{l}54.5 \\
b\end{array}$ & $\begin{array}{l}p<0 . \\
01\end{array}$ & $56.8 \mathrm{a}$ & $58.2 \mathrm{a}$ & $57.7 \mathrm{a}$ & $50.7 \mathrm{~b}$ \\
\hline Profitability & ns & $53.6 \mathrm{a}$ & $54.3 \mathrm{a}$ & $\begin{array}{l}p<0 \\
01\end{array}$ & $55.2 \mathrm{a}$ & $\begin{array}{l}52.7 \\
b\end{array}$ & ns & $55.1 \mathrm{bc}$ & $52.2 \mathrm{a}$ & $55.3 \mathrm{c}$ & $53.3 \mathrm{ab}$ \\
\hline $\begin{array}{l}\text { Stability of } \\
\text { Production }\end{array}$ & ns & $57.8 \mathrm{a}$ & $58.1 \mathrm{a}$ & ns & $58.5 \mathrm{a}$ & $\begin{array}{l}57.4 \\
\mathrm{a}\end{array}$ & $\begin{array}{l}p<0 \\
05\end{array}$ & $57.4 \mathrm{a}$ & $58.2 \mathrm{ab}$ & $59.6 b$ & $56.5 \mathrm{a}$ \\
\hline $\begin{array}{l}\text { Stability of } \\
\text { Supply }\end{array}$ & ns & $55.5 \mathrm{a}$ & $55.2 \mathrm{a}$ & $\begin{array}{l}p<0 \\
05\end{array}$ & $54.3 \mathrm{a}$ & $\begin{array}{l}56.4 \\
b\end{array}$ & $\begin{array}{l}p<0 \\
01\end{array}$ & $53 a$ & $58 \mathrm{c}$ & $55.5 \mathrm{bc}$ & $54.9 \mathrm{ab}$ \\
\hline $\begin{array}{l}\text { Stability of } \\
\text { Market }\end{array}$ & $\begin{array}{l}p<0 . \\
001\end{array}$ & $60.4 \mathrm{a}$ & $55.3 \mathrm{~b}$ & $\begin{array}{l}p<0 \\
001\end{array}$ & $61.6 \mathrm{a}$ & $54 \mathrm{~b}$ & ns & $65.1 \mathrm{vV}$ & $55.6 \mathrm{ab}$ & $58.1 \mathrm{~b}$ & $52.4 \mathrm{a}$ \\
\hline Liquidity & $\begin{array}{l}p<0 . \\
05\end{array}$ & $53.1 \mathrm{a}$ & $49.9 b$ & $\begin{array}{l}p<0 \\
05\end{array}$ & $53.6 \mathrm{a}$ & $\begin{array}{l}49.4 \\
b\end{array}$ & ns & $56.3 b$ & $49.9 \mathrm{a}$ & $50.8 \mathrm{a}$ & $48.9 \mathrm{a}$ \\
\hline $\begin{array}{l}\text { Risk } \\
\text { Management }\end{array}$ & $\begin{array}{l}p<0 . \\
001\end{array}$ & $68.3 \mathrm{a}$ & $64.9 \mathrm{~b}$ & ns & $66.3 \mathrm{a}$ & $\begin{array}{l}66.9 \\
a\end{array}$ & $\begin{array}{l}p<0 \\
05\end{array}$ & $67 b c$ & $69.5 \mathrm{c}$ & $65.5 \mathrm{ab}$ & $64.4 \mathrm{a}$ \\
\hline Food Safety & $\begin{array}{l}p<0 . \\
001\end{array}$ & $74.8 \mathrm{a}$ & $70.3 b$ & $\begin{array}{l}p<0 \\
05\end{array}$ & $73.8 \mathrm{a}$ & $\begin{array}{l}71.4 \\
b\end{array}$ & ns & $75.4 b$ & $74.3 \mathrm{ab}$ & $72.2 \mathrm{a}$ & $68.4 b$ \\
\hline Food Quality & ns & $69.1 \mathrm{a}$ & $67.4 \mathrm{a}$ & $\begin{array}{l}p<0 \\
05\end{array}$ & $69.8 \mathrm{a}$ & $\begin{array}{l}66.8 \\
b\end{array}$ & ns & $70 b$ & $68.3 \mathrm{ab}$ & $69.5 b$ & $65.4 \mathrm{a}$ \\
\hline $\begin{array}{l}\text { Product } \\
\text { Information }\end{array}$ & $\begin{array}{l}p<0 . \\
001\end{array}$ & $44.9 \mathrm{a}$ & $33.6 \mathrm{~b}$ & $\begin{array}{l}p<0 \\
001\end{array}$ & $44.5 \mathrm{a}$ & $\begin{array}{l}33.9 \\
b\end{array}$ & ns & $48.7 b$ & $41 \mathrm{a}$ & $40.3 \mathrm{a}$ & $26.9 b$ \\
\hline $\begin{array}{l}\text { Value } \\
\text { Creation }\end{array}$ & ns & $40.8 \mathrm{a}$ & $40 \mathrm{a}$ & ns & $40.1 \mathrm{a}$ & $\begin{array}{l}40.7 \\
a\end{array}$ & $\begin{array}{l}p<0 \\
01\end{array}$ & $38.9 \mathrm{a}$ & $42.6 b$ & $41.2 b$ & $38.9 \mathrm{a}$ \\
\hline $\begin{array}{l}\text { Local } \\
\text { Procurement }\end{array}$ & ns & $40.4 \mathrm{a}$ & $43.9 \mathrm{a}$ & ns & $42.9 \mathrm{a}$ & $\begin{array}{l}41.4 \\
a\end{array}$ & $\begin{array}{l}p<0 \\
001\end{array}$ & $36.9 a$ & $43.8 \mathrm{ab}$ & $48.9 b$ & $38.9 a$ \\
\hline $\begin{array}{l}\text { Quality of } \\
\text { Life }\end{array}$ & ns & $69.1 \mathrm{a}$ & $68 \mathrm{a}$ & ns & $68.4 \mathrm{a}$ & $\begin{array}{l}68.6 \\
a\end{array}$ & $\begin{array}{l}p<0 \\
01\end{array}$ & $67.7 \mathrm{ab}$ & $70.4 \mathrm{c}$ & $69.2 \mathrm{bc}$ & $66.8 \mathrm{a}$ \\
\hline $\begin{array}{l}\text { Capacity } \\
\text { Development }\end{array}$ & $\begin{array}{l}p<0 . \\
001\end{array}$ & $23 a$ & $13.6 \mathrm{~b}$ & ns & $17.5 \mathrm{a}$ & $19 a$ & ns & $20.2 b$ & $25.7 b$ & $14.8 \mathrm{a}$ & $12.3 \mathrm{a}$ \\
\hline $\begin{array}{l}\text { Fair Access to } \\
\text { Means of } \\
\text { Production }\end{array}$ & $\begin{array}{l}p<0 . \\
05\end{array}$ & $68 \mathrm{a}$ & $64.6 \mathrm{~b}$ & ns & $67.5 \mathrm{a}$ & $\begin{array}{l}65.1 \\
a\end{array}$ & $\begin{array}{l}p<0 \\
05\end{array}$ & $67.2 \mathrm{a}$ & $68.8 \mathrm{a}$ & $67.9 \mathrm{a}$ & $61.4 \mathrm{~b}$ \\
\hline $\begin{array}{l}\text { Responsible } \\
\text { Buyers }\end{array}$ & ns & $63.2 \mathrm{a}$ & $64.2 \mathrm{a}$ & ns & $63.9 \mathrm{a}$ & $\begin{array}{l}63.6 \\
a\end{array}$ & $\begin{array}{l}p<0 \\
001\end{array}$ & $61.3 \mathrm{a}$ & $65.2 \mathrm{bc}$ & $66.5 \mathrm{c}$ & $62 \mathrm{ab}$ \\
\hline $\begin{array}{l}\text { Rights of } \\
\text { Suppliers }\end{array}$ & ns & $59.3 \mathrm{a}$ & $59.8 \mathrm{a}$ & ns & $58.3 \mathrm{a}$ & $\begin{array}{l}60.7 \\
a\end{array}$ & $\begin{array}{l}p<0 \\
01\end{array}$ & $55.9 \mathrm{a}$ & $62.6 b$ & $60.8 b$ & $58.8 \mathrm{ab}$ \\
\hline $\begin{array}{l}\text { Employment } \\
\text { Relations }\end{array}$ & ns & $70.1 \mathrm{a}$ & $69.1 \mathrm{a}$ & ns & $70 \mathrm{a}$ & $\begin{array}{l}69.3 \\
a\end{array}$ & ns & $69.9 b$ & $70.4 \mathrm{ab}$ & $70.1 \mathrm{~b}$ & $68.1 \mathrm{a}$ \\
\hline $\begin{array}{l}\text { Forced } \\
\text { Labour }\end{array}$ & $\begin{array}{l}p<0 . \\
001\end{array}$ & $66.3 \mathrm{a}$ & $60.2 b$ & $\begin{array}{l}p<0 \\
01\end{array}$ & $65.1 \mathrm{a}$ & $\begin{array}{l}61.4 \\
b\end{array}$ & ns & $67.5 b$ & $65.1 \mathrm{ab}$ & $62.6 \mathrm{a}$ & $57.7 \mathrm{~b}$ \\
\hline Child Labour & $\begin{array}{l}p<0 . \\
001\end{array}$ & $77 \mathrm{a}$ & $72.5 b$ & $\begin{array}{l}p<0 \\
001\end{array}$ & $77.8 \mathrm{a}$ & $\begin{array}{l}71.7 \\
b\end{array}$ & $\begin{array}{l}p<0 \\
05\end{array}$ & $79 b$ & $75.1 \mathrm{a}$ & $76.5 \mathrm{a}$ & $68.4 b$ \\
\hline $\begin{array}{l}\text { Freedom of } \\
\text { Association } \\
\text { and Right to } \\
\text { Bargaining }\end{array}$ & $\begin{array}{l}p<0 . \\
001\end{array}$ & $54 \mathrm{a}$ & $46.8 b$ & ns & $51 \mathrm{a}$ & $\begin{array}{l}49.7 \\
a\end{array}$ & ns & $53.6 \mathrm{a}$ & $54.3 \mathrm{a}$ & $48.3 \mathrm{a}$ & $45.2 b$ \\
\hline $\begin{array}{l}\text { Non } \\
\text { discriminatio } \\
\mathrm{n}\end{array}$ & ns & $65.8 \mathrm{a}$ & $65.8 \mathrm{a}$ & ns & $66.4 \mathrm{a}$ & $\begin{array}{l}65.2 \\
a\end{array}$ & ns & $65.6 \mathrm{a}$ & $66 a$ & $67.2 \mathrm{a}$ & $64.5 \mathrm{a}$ \\
\hline $\begin{array}{l}\text { Gender } \\
\text { Equality }\end{array}$ & ns & $70.9 a$ & $71.5 \mathrm{a}$ & ns & $72.2 \mathrm{a}$ & $\begin{array}{l}70.2 \\
a\end{array}$ & ns & $71.1 \mathrm{a}$ & $70.7 \mathrm{a}$ & $73.3 \mathrm{a}$ & $69.7 \mathrm{a}$ \\
\hline $\begin{array}{l}\text { Support to } \\
\text { Vulnerable } \\
\text { People }\end{array}$ & $\begin{array}{l}p<0 . \\
001\end{array}$ & $41.4 \mathrm{a}$ & $35.6 \mathrm{~b}$ & ns & $38.3 \mathrm{a}$ & $\begin{array}{l}38.7 \\
\mathrm{a}\end{array}$ & ns & $40.1 b$ & $42.8 b$ & $36.6 \mathrm{a}$ & $34.7 \mathrm{a}$ \\
\hline $\begin{array}{l}\text { Workplace } \\
\text { Safety and } \\
\text { Health } \\
\text { Provisions }\end{array}$ & $\begin{array}{l}p<0 . \\
01\end{array}$ & $71 \mathrm{a}$ & $68 \mathrm{~b}$ & ns & $69.7 \mathrm{a}$ & $\begin{array}{l}69.3 \\
\mathrm{a}\end{array}$ & $\begin{array}{l}p<0 \\
05\end{array}$ & $70.1 \mathrm{a}$ & $71.9 \mathrm{a}$ & $69.4 \mathrm{a}$ & $66.7 \mathrm{~b}$ \\
\hline Public Health & $\begin{array}{l}p<0 . \\
001\end{array}$ & $77 \mathrm{a}$ & 73.2 & ns & $75 \mathrm{a}$ & $\begin{array}{l}75.2 \\
\mathrm{a}\end{array}$ & ns & $76.4 b$ & $77.7 \mathrm{~b}$ & $73.7 \mathrm{a}$ & $72.7 \mathrm{a}$ \\
\hline $\begin{array}{l}\text { Indigenous } \\
\text { Knowledge }\end{array}$ & ns & $82 \mathrm{a}$ & $80.4 \mathrm{a}$ & $\begin{array}{l}p<0 \\
01\end{array}$ & $83.9 \mathrm{a}$ & $\begin{array}{l}78.5 \\
b\end{array}$ & ns & $83.7 \mathrm{~b}$ & $80.3 \mathrm{ab}$ & $84.2 \mathrm{~b}$ & $76.6 a$ \\
\hline $\begin{array}{l}\text { Food } \\
\text { Sovereignty }\end{array}$ & ns & $66.8 \mathrm{a}$ & $64.8 \mathrm{a}$ & ns & $66.5 \mathrm{a}$ & $\begin{array}{l}65.1 \\
\mathrm{a}\end{array}$ & $\begin{array}{l}p<0 . \\
01\end{array}$ & $65.5 \mathrm{a}$ & $68.1 \mathrm{a}$ & $67.5 \mathrm{a}$ & $62.1 \mathrm{~b}$ \\
\hline
\end{tabular}


Table 2 (continued)

Details on the standard errors of means and significance levels of subtheme scores for the five farm types in the two counties and interaction effects can be found in Appendix A (Table S2 and S3 and Fig. S1). Means with different letters within columns in each factor category (i.e. certification status, county or their combination) indicate significant differences between factors at $p<0.05$ based on LSD post hoc test. Cell colours indicate subthemes belonging to the same sustainability dimension

$n s=$ not significant at $p<0.05$

* Sustainability Monitoring and Assessment RouTine (SMART)-Farm Tool

Table 3 Mean sustainability scores (i.e. average RI values) from the SMART-Farm tool of indicators across 4 sustainability dimensions related to land and crop management with significance of differences between certified and non-certified farms according to generalized linear models

Indicator Indicator title
unique

\begin{tabular}{|c|c|c|c|c|}
\hline 34.2 & Use of chemical synthetic seed dressings & $p<0.001$ & $18.9 \mathrm{a}$ & $11.4 \mathrm{~b}$ \\
\hline 202 & Agroforestry systems & $p<0.01$ & $8.8 \mathrm{a}$ & $6.4 \mathrm{~b}$ \\
\hline 222 & Permanent grasslands: Share of agricultural area & $p<0.05$ & $3.9 \mathrm{a}$ & $1.9 \mathrm{~b}$ \\
\hline 229 & Ecological compensation areas: Share of agricultural land & $p<0.001$ & $15.6 \mathrm{a}$ & $11.7 \mathrm{~b}$ \\
\hline 253 & Permanent grasslands: Extensively managed & $p<0.01$ & $3.4 \mathrm{a}$ & $11.8 \mathrm{~b}$ \\
\hline 257.1 & Pesticides: toxicity bees & $p<0.05$ & $60 \mathrm{a}$ & $55.1 \mathrm{~b}$ \\
\hline 257.2 & Pesticides: toxicity aquatic organisms & $p<0.05$ & $60.7 \mathrm{a}$ & $54.9 \mathrm{~b}$ \\
\hline 286 & Soil degradation: measures taken to counter & $p<0.05$ & $30.5 \mathrm{a}$ & $27.2 b$ \\
\hline 290 & Determining fertilizer requirements & $p<0.05$ & $8.4 \mathrm{a}$ & $6.4 \mathrm{~b}$ \\
\hline 298 & $\begin{array}{l}\text { Soil improvement: proportion of formerly degraded land } \\
\text { regenerated }\end{array}$ & $p<0.001$ & $26.7 \mathrm{a}$ & $33.9 \mathrm{~b}$ \\
\hline 322 & Mineral potassium fertilizers & $p<0.001$ & $4.6 \mathrm{a}$ & $16 b$ \\
\hline 377.1 & Pesticides: number of active substances & $p<0.05$ & $65.3 \mathrm{a}$ & $59.5 b$ \\
\hline 377.5 & Pesticides: chronic toxicity & $p<0.05$ & $68.9 \mathrm{a}$ & $63.2 b$ \\
\hline 710 & Harmful substances: phosphorous-fertilizers & $p<0.05$ & $11.6 \mathrm{a}$ & $6.6 \mathrm{a}$ \\
\hline 128.1 & Yield level & ns & $36.1 \mathrm{a}$ & $39.1 \mathrm{a}$ \\
\hline 206 & Share of legumes on arable land & ns & $21.3 \mathrm{a}$ & $22.8 \mathrm{a}$ \\
\hline 244 & Number of scattered fruit trees & ns & $22.4 \mathrm{a}$ & $20.4 \mathrm{a}$ \\
\hline 289 & Humus formation: crop residues & ns & $9.9 \mathrm{a}$ & $10 \mathrm{a}$ \\
\hline 296 & Soil degradation: share of agricultural area & ns & $60.4 \mathrm{a}$ & $61.9 \mathrm{a}$ \\
\hline 323 & Mineral nitrogen fertilizers & ns & $32.5 \mathrm{a}$ & $29.7 \mathrm{a}$ \\
\hline 324 & Mineral phosphorous fertilizers & ns & $31.7 \mathrm{a}$ & $29.1 \mathrm{a}$ \\
\hline 519 & Use of GMO crops & $\mathrm{ns}$ & $36.6 \mathrm{a}$ & $39.4 \mathrm{a}$ \\
\hline 605 & Management of riparian strips & $\mathrm{ns}$ & $30.4 \mathrm{a}$ & $30.8 \mathrm{a}$ \\
\hline 700 & Measures to prevent erosion & ns & $16.2 \mathrm{a}$ & $15.9 \mathrm{a}$ \\
\hline 740 & Growth regulation & $\mathrm{ns}$ & $58.5 \mathrm{a}$ & $55.5 \mathrm{a}$ \\
\hline 758 & Number of perennial crops & ns & $47.2 \mathrm{a}$ & $48.3 \mathrm{a}$ \\
\hline
\end{tabular}

Means with different letters within the same row show significant differences in indicators for farms between certified and non-certified farms at $p<0.05$

${ }^{\mathrm{x}}$ For a detailed description of the indicators, please refer to a detailed described in Supplementary Material A of (Schader et al., 2016)

$n s=$ not significant at $p<0.05$ 
Table 4 Average RI values from the SMART-Farm Tool of high impact indicators (weight $>0.6$ ) for certified and non-certified farms and significance levels from generalized linear models (letters indicate significant differences at $p<0.05, \mathrm{~ns}=$ not significant)

\begin{tabular}{|c|c|c|c|c|c|}
\hline Dimension & $\begin{array}{l}\text { Indicator } \\
\text { unique ID }\end{array}$ & Indicator & $p$ & Certified & Non-certified \\
\hline \multirow{8}{*}{$\begin{array}{c}\text { Good } \\
\text { Governance }\end{array}$} & 460 & Proactive support of disadvantaged groups & $p<0.05$ & $53.6 \mathrm{a}$ & $46.4 \mathrm{~b}$ \\
\hline & 0 & Professional agricultural accounts & ns & $28.5 \mathrm{a}$ & $28.5 \mathrm{a}$ \\
\hline & 423 & Workers: Legally binding contracts & ns & $59.4 \mathrm{a}$ & $60.7 \mathrm{a}$ \\
\hline & 63 & Proportion of environmentally certified products & $p<0.001$ & $20.6 \mathrm{a}$ & $8 \mathrm{~b}$ \\
\hline & 327 & Waste disposal: Pesticides and veterinary medicines & $p<0.001$ & $61.4 \mathrm{a}$ & $48 \mathrm{~b}$ \\
\hline & 175 & Transparency of production & $p<0.001$ & $26.6 \mathrm{a}$ & $8.5 b$ \\
\hline & 322 & Mineral potassium fertilisers & $p<0.001$ & $4.6 \mathrm{a}$ & $16 b$ \\
\hline & 375 & Animal welfare standards (slaughter) & $p<0.05$ & $32 \mathrm{a}$ & $28 \mathrm{~b}$ \\
\hline \multirow{15}{*}{$\begin{array}{l}\text { Environmental } \\
\text { Integrity }\end{array}$} & 723 & Buying new animals & $\mathrm{ns}$ & $27.3 \mathrm{a}$ & $27.7 \mathrm{a}$ \\
\hline & 725 & Pig keeping: quarantine section & $p<0.001$ & $15.5 \mathrm{a}$ & $8.7 \mathrm{~b}$ \\
\hline & 253 & Permanent grasslands: extensively managed & $p<0.01$ & $3.4 \mathrm{a}$ & $11.8 \mathrm{~b}$ \\
\hline & 726 & Polishing piglet teeth & ns & $18.2 \mathrm{a}$ & $18 \mathrm{a}$ \\
\hline & 322 & Mineral potassium fertilisers & $p<0.001$ & $4.6 \mathrm{a}$ & $16 \mathrm{~b}$ \\
\hline & 327 & Waste disposal: Pesticides and veterinary medicines & $p<0.001$ & $61.4 \mathrm{a}$ & $48 b$ \\
\hline & 244 & Number of scattered fruit trees & ns & $22.4 \mathrm{a}$ & $20.4 \mathrm{a}$ \\
\hline & 335.1 & Recycling of paper/cardboards & $p<0.001$ & $20.2 \mathrm{a}$ & $13 \mathrm{~b}$ \\
\hline & 377.05 & Wastewater disposal & ns & $44.1 \mathrm{a}$ & $42.1 \mathrm{a}$ \\
\hline & 387 & Water use efficiency & $\mathrm{ns}$ & $51.3 \mathrm{a}$ & $50.7 \mathrm{a}$ \\
\hline & 371 & Access to pasture for ruminants & $p<0.001$ & $4.1 \mathrm{a}$ & $9.6 \mathrm{~b}$ \\
\hline & 722 & Injuries of pigs & ns & $33.6 \mathrm{a}$ & $33.6 \mathrm{a}$ \\
\hline & 357 & Mutilation: Use of anaesthetics and analgesics & ns & $22.7 \mathrm{a}$ & $27.4 \mathrm{a}$ \\
\hline & 375 & Animal welfare standards (slaughter) & $p<0.05$ & $32 \mathrm{a}$ & $28 b$ \\
\hline & 337 & Loss of agricultural products (food waste) & $p<0.001$ & $40.4 \mathrm{a}$ & $49.7 b$ \\
\hline \multirow{13}{*}{$\begin{array}{l}\text { Economic } \\
\text { Resilience }\end{array}$} & 63 & Proportion of environmentally certified products & $p<0.001$ & $20.6 \mathrm{a}$ & $8 \mathrm{~b}$ \\
\hline & 175 & Transparency in production & $p<0.001$ & $26.6 \mathrm{a}$ & $8.5 \mathrm{~b}$ \\
\hline & 473 & $\begin{array}{l}\text { Workers: Training in use of plant protection and animal treatment } \\
\text { products }\end{array}$ & $\mathrm{ns}$ & $63.3 \mathrm{a}$ & $60.5 \mathrm{a}$ \\
\hline & 72 & Further training for farm staff & $p<0.001$ & $26.5 \mathrm{a}$ & $15.1 \mathrm{~b}$ \\
\hline & 73 & Long-term investments & $p<0.05$ & $52.5 \mathrm{a}$ & $44.4 b$ \\
\hline & 158 & Diversification of income & $p<0.001$ & $46.8 \mathrm{a}$ & $27.2 b$ \\
\hline & 65 & Proportion of products meeting social standards & $p<0.001$ & $17.9 \mathrm{a}$ & $7.2 \mathrm{~b}$ \\
\hline & 0 & Professional agricultural accounts & ns & $28.5 \mathrm{a}$ & $28.5 \mathrm{a}$ \\
\hline & 723 & Buying new animals & ns & $27.3 \mathrm{a}$ & $27.7 \mathrm{a}$ \\
\hline & 83 & Diversification of sales & $p<0.05$ & $63.4 \mathrm{a}$ & $53.4 \mathrm{~b}$ \\
\hline & 371 & Access to pasture for ruminants & $p<0.001$ & $4.1 \mathrm{a}$ & $9.6 \mathrm{~b}$ \\
\hline & 95 & Yield loss & $p<0.001$ & $25.9 \mathrm{a}$ & $39.1 \mathrm{~b}$ \\
\hline & 722 & Injuries of pigs & ns & $33.6 \mathrm{a}$ & $33.6 \mathrm{a}$ \\
\hline \multirow{9}{*}{$\begin{array}{c}\text { Social } \\
\text { Well-Being }\end{array}$} & 72 & Further training for farm staff & $p<0.001$ & $26.5 \mathrm{a}$ & $15.1 \mathrm{~b}$ \\
\hline & 703 & Access to advisory services & $p<0.05$ & $57.5 \mathrm{a}$ & $51 \mathrm{~b}$ \\
\hline & 423 & Workers: Legally binding contracts & ns & $59.4 \mathrm{a}$ & $60.7 \mathrm{a}$ \\
\hline & 463.1 & Workers: Permanent workforce & $p<0.001$ & $5.6 \mathrm{a}$ & $2.1 \mathrm{~b}$ \\
\hline & 463.2 & Workers: Social protection & $p<0.001$ & $17.2 \mathrm{a}$ & $7.7 \mathrm{~b}$ \\
\hline & 460 & Proactive support of disadvantaged groups & $p<0.05$ & $53.6 \mathrm{a}$ & $46.4 b$ \\
\hline & 327 & Waste disposal: Pesticides and veterinary medicines & $p<0.001$ & $61.4 \mathrm{a}$ & $48 b$ \\
\hline & 377.05 & Wastewater disposal & ns & $44.1 \mathrm{a}$ & $42.1 \mathrm{a}$ \\
\hline & 725 & Pig keeping: Quarantine section & $p<0.001$ & $15.5 \mathrm{a}$ & $8.7 \mathrm{~b}$ \\
\hline
\end{tabular}

Cell colours indicate subthemes belonging to the same sustainability dimension. Means with different letters within the same row show significant differences in indicators for farms between the certified and noncertified farms at $\mathrm{p}<0.05$. Cell colours indicate subthemes belonging to the same sustainability dimension

${ }^{\mathrm{x}}$ For a detailed description of the indicators, please refer to a detailed described in Supplementary Material A of (Schader et al., 2016) using unique ID (identification) numbers

$n s=$ not significant at $p<0.05$

has been reported in Kajiado (Kabubo-Mariara et al., 2009). To further reduce conflict, ongoing land reforms in Kenya should seek to secure access to land and other resources for smallholder farmers (WFP, 2016). 
Table 5 Average RI values from the SMART-Farm Tool of high impact indicators (weight $>0.6$ ) for farms in Kenya's Murang'a and Kajiado counties and significance levels

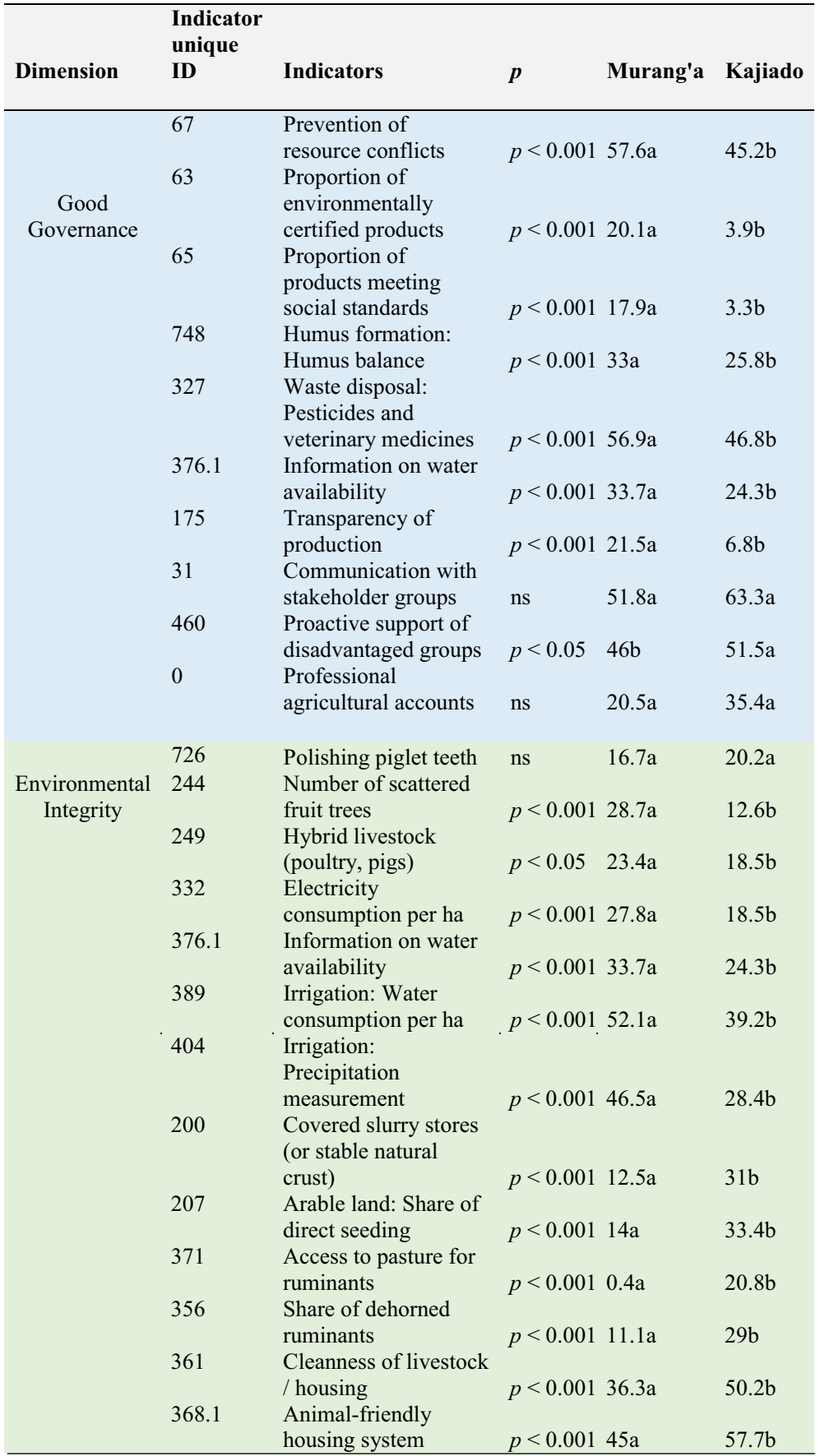


Table 5 (continued)

\begin{tabular}{|c|c|c|c|c|c|}
\hline & 369 & $\begin{array}{l}\text { Number and quality } \\
\text { of drinking points }\end{array}$ & $p<0.001$ & $48.5 \mathrm{a}$ & $58.6 b$ \\
\hline & 370.5 & $\begin{array}{l}\text { Daily outdoor access } \\
\text { for animals }\end{array}$ & $p<0.001$ & $5 a$ & $25.4 b$ \\
\hline & 723 & Buying new animals & ns & $27.8 \mathrm{a}$ & $27.5 \mathrm{a}$ \\
\hline & 725 & Pig keeping: & & & \\
\hline & & Quarantine section & ns & $10.5 \mathrm{a}$ & $11 \mathrm{a}$ \\
\hline & 701 & Loose-housing system & $p<0.05$ & $19.7 \mathrm{a}$ & $28.3 b$ \\
\hline & 728 & $\begin{array}{l}\text { Materials to keep } \\
\text { animals busy }\end{array}$ & $p<0.01$ & $15.3 \mathrm{a}$ & $25.2 \mathrm{~b}$ \\
\hline & 620 & Permanent grasslands: & & & \\
\hline & & mowing frequency & ns & $22.9 \mathrm{a}$ & $20.1 \mathrm{a}$ \\
\hline Economic & 63 & $\begin{array}{l}\text { Proportion of } \\
\text { environmentally } \\
\text { certified products }\end{array}$ & $p<0.001$ & $20.1 \mathrm{a}$ & $3.9 \mathrm{~b}$ \\
\hline Resilience & 146 & Product returns & $p<0.001$ & $65.5 \mathrm{a}$ & $39.6 \mathrm{~b}$ \\
\hline & 170 & Food safety standard & ns & $5.6 \mathrm{a}$ & $0 \mathrm{~b}$ \\
\hline & 175 & $\begin{array}{l}\text { Transparency of } \\
\text { production }\end{array}$ & $p<0.001$ & $21.5 \mathrm{a}$ & $6.8 b$ \\
\hline & 73 & Long-term & & & \\
\hline & & investments & $p<0.001$ & $52 \mathrm{a}$ & $41.2 b$ \\
\hline & 286 & Soil degradation: & & & \\
\hline & & $\begin{array}{l}\text { Measures to counter } \\
\text { degradation }\end{array}$ & $p<0.001$ & $32.9 \mathrm{a}$ & $23.2 b$ \\
\hline & 298 & Soil improvement & $p<0.001$ & $36.7 \mathrm{a}$ & $26.1 \mathrm{~b}$ \\
\hline & 244 & $\begin{array}{l}\text { Number of scattered } \\
\text { fruit trees }\end{array}$ & $p<0.001$ & $28.7 \mathrm{a}$ & $12.6 \mathrm{~b}$ \\
\hline & 767 & Land ownership & & & \\
\hline & & (secure tenure rights) & $p<0.001$ & $56.6 \mathrm{a}$ & $49.2 b$ \\
\hline & 65 & $\begin{array}{l}\text { Proportion of } \\
\text { products meeting }\end{array}$ & & & \\
\hline & & social standards & $p<0.001$ & $17.9 \mathrm{a}$ & $3.3 b$ \\
\hline & 775 & $\begin{array}{l}\text { Commercially viable } \\
\text { size of main business }\end{array}$ & & & \\
\hline & & unit(s) & $p<0.001$ & $70.2 \mathrm{a}$ & $55.8 \mathrm{~b}$ \\
\hline & 149 & Length of customer & & & \\
\hline & & relationships & $p<0.001$ & $40.3 \mathrm{a}$ & $25.8 b$ \\
\hline & 249 & $\begin{array}{l}\text { Hybrid livestock } \\
\text { (poultry, pigs) }\end{array}$ & $p<0.05$ & $23.4 \mathrm{a}$ & $18.5 b$ \\
\hline & 758 & Number of perennial & & & \\
\hline & & crops & $p<0.001$ & $13.4 \mathrm{a}$ & $0.4 b$ \\
\hline & 370.5 & Daily outdoor access & & & \\
\hline & & for animals & $p<0.001$ & $5 a$ & $25.4 \mathrm{~b}$ \\
\hline & 371 & $\begin{array}{l}\text { Access to pasture for } \\
\text { ruminants }\end{array}$ & $p<0.001$ & $0.4 \mathrm{a}$ & $20.8 b$ \\
\hline & 723 & Buying new animals & ns & $27.8 \mathrm{a}$ & $27.5 \mathrm{a}$ \\
\hline & 152 & Loan (credit) limit & $p<0.05$ & $18.7 \mathrm{a}$ & $31.3 \mathrm{a}$ \\
\hline & 0 & Professional & $n^{n}$ & & \\
\hline & 100 & $\begin{array}{l}\text { Market challenges } \\
\text { Macturats }\end{array}$ & ns & $20.5 a$ & $55.4 a$ \\
\hline & & (farmer information) & $p<0.001$ & $41.5 \mathrm{a}$ & $50.5 b$ \\
\hline & 244 & Number of scattered & & & \\
\hline & & fruit trees & $p<0.001$ & $28.7 \mathrm{a}$ & $12.6 b$ \\
\hline & 207 & $\begin{array}{l}\text { Arable land: Share of } \\
\text { direct seeding }\end{array}$ & $p<0.001$ & $14 \mathrm{a}$ & $33.4 \mathrm{~b}$ \\
\hline & 369 & Number and quality & & & \\
\hline & & of drinking points & $p<0.001$ & $48.5 \mathrm{a}$ & $58.6 \mathrm{~b}$ \\
\hline
\end{tabular}


Table 5 (continued)

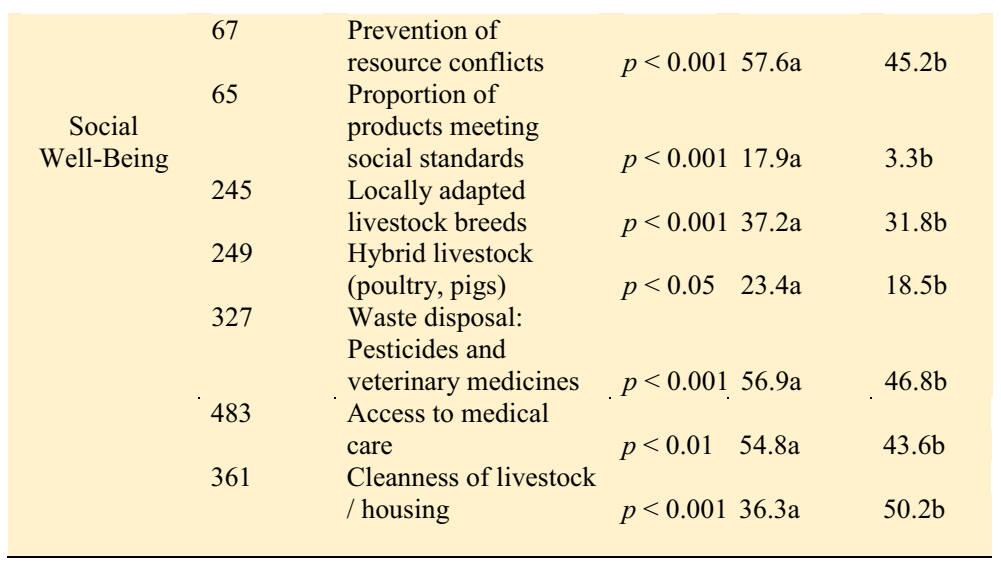

Means with different letters within the same row show significant differences in indicators for farms between the two counties (Murang'a and Kajiado) at $\mathrm{p}<0.05$

${ }^{\mathrm{x}}$ For a detailed description of the indicators, please refer to a detailed described in Supplementary Material A of (Schader et al., 2016) using unique ID (identification) numbers

Cell colours indicate subthemes belonging to the same sustainability dimension

$n s=$ not significant at $p<0.05$

\subsubsection{Water management and quality}

Within the Environmental Integrity dimension, the water quality subtheme scores were significantly higher in certified organic farms (Table 2), which was explained partly by indicators that showed significantly lower pesticide use and higher information availability about water quality (Tables 4 and 5). The two counties differed considerably in water withdrawal but not in water quality (Table 2). Farms in Kajiado had significantly less information on water availability, used more water for irrigation annually, and they did not measure or record precipitation which helps in calculating irrigation water demand (Table 5).

These results indicate that water quality is reduced in smallholder farms that use agrochemicals and there is poor management of irrigation water particularly in the dry ASAL regions where water is already a limited resource and irrigation is needed. Agriculture is the leading water user in Kenya constituting over $70 \%$ of the country's water use per annum (FAO, 2005). However, although the area under irrigated agriculture is still minimal in Kenya, with only $2.4 \%$ of the arable land under irrigation, it accounts for, more than $50 \%$ of the water used in agriculture (WRMA, 2013). In Kajiado, the need for irrigation on recently converted land has increased competition for water resources (Adhiambo et al., 2017) and to a reduction in river water quantity and quality over time (Adhiambo et al., 2017; Gichuki \& Macharia, 2006). This shows a need for increased awareness on water use, management and storage particularly with ongoing efforts to increase the area under irrigation in Kenya and to improve regulations in water management (WRMA, 2013). Capacity development in irrigation schemes for the Kenyan ASAL regions could decrease regional poverty and food insecurity (Mati, 2008). 


\subsection{Limitations}

The SMART-Farm Tool performs well in comparison with other tools used in decision making at farm level (Arulnathan et al., 2020). To enable comparability of results, the indicators included are broadly defined for different farm types, settings, climatic conditions and socio-economic contexts. This global applicability is important to enable comparability of results (Schader et al., 2016). However, the drawback of this generic approach is that it does not take into account all case- and site-specific factors that may influence sustainability.

One limitation of the approach in this study is the inability to draw general conclusions about the specific impacts of certification or biophysical differences on these farms, without a more targeted assessment. Although our results indicate differences between the two counties as well as certified and non-certified farms, we hesitate to describe the results of in terms of cause-and-effect. The comparability and the explanatory power of such multicriteria sustainability assessments could increase if they were harmonized and aligned. A first step for such a harmonization could be the agreement on a common framework such as the SDGs translated to goals that are applicable at the farm level.

\section{Conclusions}

In this study, we assessed the sustainability performance of smallholder farms by applying the SMART-Farm Tool based on the dimensions of Good Governance, Environmental Integrity, Economic Resilience and Social Well-Being. We sought to contribute to the ongoing debate on the effectiveness of agricultural systems in contributing to sustainable development and the role of OA in Kenya and beyond. The findings from our case studies in the counties of Murang'a and Kajiado in Kenya demonstrate the need to close the gap in education, knowledge and skills of smallholder farmers, as well as to build job and social safety nets for farmers and farm workers. Our findings indicate that organic certification could play a role in reducing these knowledge gaps thereby contributing to farm-level social sustainability and good governance. OA can also strengthen farms economic resilience through long-term farm investments and diversification.

In addition, our results demonstrate that organic certification is linked to greater biodiversity, soil and water quality levels, which could play a role in tackling the problem of declining soil health in Kenya and possibly elsewhere in SSA, thereby enhancing environmental integrity and climate resilience. However, except for better handling of agrochemicals and a few other practices like more agroforestry systems, the lack of differences in many land and crop management practices of certified farms and non-certified farms implies that the OA attempts to increase environmental sustainability (Raynolds et al., 2007) could be undermined unless certified organic farms adhere to most of the practices required in the practice $\mathrm{OA}$.

Our findings suggest that organic farms can perform better or at least as well as conventional ones in terms of biodiversity enhancement, water management, use and management of agrochemicals, farmer and farm worker well-being and training in farm management even for people with limited or no formal education. Other studies carried out in SSA that reported improvement in profitability, social capital and reduced poverty levels in farms where $\mathrm{OA}$ is practiced reinforce our findings that $\mathrm{OA}$ is a valid pro-poor growth strategy in SSA. 
The sustainability performance of smallholder farms was also shown to be associated with differences in biophysical conditions. This is important for Kenya, a country that is predominantly dry and relying on rainfed agriculture, which exposes farmers to environmental shocks. To advance the sustainability of the farms and overcome low adoption of soil conservation measures and other long-term farm investments in ASAL regions in Kenya, we see a need to increase access to these assets and strengthen land-tenure rights in ASAL regions. Capacity building and fostering regulation and support in water management for farms in ASAL regions could also play a role in improving food security and reducing poverty as the area under irrigation expands in Kenya. For relatively humid areas like Murang'a that tend to have a higher population density than ASAL regions, poor animal husbandry practices should be addressed despite continuing land fragmentation. Farmers also need better linkage to farm input, farm output and credit markets in efforts aiming to advance the sustainability of farms.

To expand on this study, future research could explore topics such as the causal effects of certification in relation to the different themes of sustainability. This will provide more information about the potential of land-use change to address the looming environmental crisis and rapid population growth and exacerbated resource scarcity expected in this region. Further focus on animal husbandry practices (such as manure handling and livestock carrying capacity) on smallholder farms in SSA is also needed, given the negative effects on human and animal welfare and the environment.

\section{Implications}

Assessing sustainability in smallholder farms is complex, as shown in this and other such studies. Enhancing their sustainability performance is equally complex, given the need to balance different and sometimes conflicting objectives. Nevertheless, we have highlighted some areas that can be strengthened to bring win-win situations across different dimensions.

Strengthening the knowledge and skills among smallholder farmers will enable them to adopt sustainable farming practices. The state can play a vital role through investment in innovation and knowledge development and dissemination. In SSA, this investment remains very low and there is over-reliance on non-state actors. Investments in training on all aspects of the value chain from production to the market could help. This includes soil fertility management, safe use of agrochemicals, bookkeeping, produce marketing, and other relevant technical skills. This training could cover aspects of declining soil fertility and its effects on productivity, yields and food security in SSA. Specific training for OA would allow the adjustment of OA rules to suit the situation not just in Kenya, but Africa as a whole. Even where knowledge and its dissemination mechanisms exist, there is a need for more coordination and investments in technical and personnel capacities.

In addition, these farmers need access to productive assets including capital, credit and secure land tenure to enable them to make long-term investments. They also need access to increased diversified social protection mechanisms. The rapid growth in demand of organic produce internationally, regionally and locally offers a premium market that farmers can take advantage of, with the support of initiatives like the EOA by the African Union, while taking into account all the potential bottlenecks of sustainability of OA highlighted in this study. 
This study gives some indication of where gaps in sustainability exist for smallholder farms in Kenya. However, more targeted on biodiversity and soil fertility in smallholder farming SSA, including the role of soil microbiota in different farming systems in SSA could shed more light on sustainability gaps. In addition, the area of the environmental impacts of animal husbandry, particularly in relation of animal welfare and greenhouse gas emissions, needs further scientific exploration. The expansion of intensification of agriculture that is expected in SSA will lead to an increase in the share of land under irrigation as well as agrochemical use, particularly in dry ASAL regions. This will likely have implications on water withdrawal and water quality. Further research that explores this dynamic of agricultural intensification, water use and water quality changes will also be important for understanding and managing these changes. Further research will need to transcend boundaries of academic disciplines to capture the interconnected dimensions and indicators of sustainability.

The findings of our study offer a starting point for a more comprehensive and allencompassing discourse on farm-level agricultural sustainability. Development interventions, strategies and policies aiming to improve the sustainability performance of smallholder farms in Kenya, similar regions in SSA and beyond, can begin with addressing the gaps in sustainability highlighted in this study.

Supplementary Information The online version contains supplementary material available at https:/doi. org/10.1007/s10668-021-01736-y.

Acknowledgements The authors would like to thank the funding institutions including the University of Bonn, Research Institute of Organic Agriculture (FiBL)-Frick co-funded by the Dutch Humanist Institute for Cooperation (Hivos), the Swiss Agency for Development and Co-operation (SDC) and the Mercator Foundation Switzerland through the ProEcoAfrica and OFSA projects (www.proecoafrica.net). It was further supported by funds from the World Agroforestry Centre (ICRAF), the Swedish Society for Nature Conservation (SSNC) through Biovision Foundation and Biovision Africa Trust (BvAT) and the German Federal Ministry of Education and Research within the project LANUSYNCON (At the Science Policy Interface: LANd Use SYNergies and CONflicts within the framework of the 2030 Agenda). The authors' gratitude extends to the International Centre for Insect Physiology and Ecology (icipe) for providing research support and a base from which the fieldwork was conducted. The authors thank Guido Lüchters for his guidance in data analysis. Finally, thank the reviewers who contributed to improving the quality of this manuscript, the field research team and the farmers who participated in this study.

Funding Open Access funding enabled and organized by Projekt DEAL.

Open Access This article is licensed under a Creative Commons Attribution 4.0 International License, which permits use, sharing, adaptation, distribution and reproduction in any medium or format, as long as you give appropriate credit to the original author(s) and the source, provide a link to the Creative Commons licence, and indicate if changes were made. The images or other third party material in this article are included in the article's Creative Commons licence, unless indicated otherwise in a credit line to the material. If material is not included in the article's Creative Commons licence and your intended use is not permitted by statutory regulation or exceeds the permitted use, you will need to obtain permission directly from the copyright holder. To view a copy of this licence, visit http://creativecommons.org/licenses/by/4.0/.

\section{References}

Adamtey, N., Musyoka, M. W., Zundel, C., Cobo, J. G., Karanja, E., Fiaboe, K. K. M., et al. (2016). Productivity, profitability and partial nutrient balance in maize-based conventional and organic farming systems in Kenya. Agriculture, Ecosystems and Environment, 235, 61-79. https://doi.org/10.1016/j. agee.2016.10.001 
Adhiamb o, M. P., Kironchi, G., Mureithi, S., \& Kathumo, V. (2017). Assessing land use and land cover change using participatory geographical information system (PGIS) approach in Nguruman Subcatchment, Kajiado north Sub county, Kenya. Journal of Geography and Regional Planning, 10(8), 219-228. https://doi.org/10.5897/JGRP2016.0606

Aliloo, A. A., \& Dashti, S. (2021). Rural sustainability assessment using a combination of multi-criteria decision making and factor analysis. Environment, Development and Sustainability, 23(4), 63236336. https://doi.org/10.1007/s10668-020-00874-Z

Altieri, M. A. (2009). Agroecology, small farms, and food sovereignty. Monthly Review, 61(3), 102.

Angevin, F., Fortino, G., Bockstaller, C., Pelzer, E., \& Messéan, A. (2017). Assessing the sustainability of crop production systems: Toward a common framework? Crop Protection, 97(Supplement C), 18-27. https://doi.org/10.1016/j.cropro.2016.11.018

Anyango, J. J., Bautze, D., Fiaboe, K. K. M., Lagat, Z. O., Muriuki, A. W., Stöckli, S., et al. (2020). The impact of conventional and organic farming on soil biodiversity conservation: A case study on termites in the long-term farming systems comparison trials in Kenya. BMC Ecology, 20(1), 13. https:// doi.org/10.1186/s12898-020-00282-x

Arulnathan, V., Heidari, M. D., Doyon, M., Li, E., \& Pelletier, N. (2020). Farm-level decision support tools: A review of methodological choices and their consistency with principles of sustainability assessment. Journal of Cleaner Production, 256, 120410. https://doi.org/10.1016/j.jclepro.2020.120410

Asenso-Okyere, K. (2009). Building capacity to increase agricultural productivity and incomes of poor small-scale farmers. Washington: International Food Policy Research Institute.

Ayuya, O. I., Gido, E. O., Bett, H. K., Lagat, J. K., Kahi, A. K., \& Bauer, S. (2015). Effect of certified organic production systems on poverty among smallholder farmers: Empirical evidence from Kenya. World Development, 67, 27-37. https://doi.org/10.1016/j.worlddev.2014.10.005

Badgley, C., Moghtader, J., Quintero, E., Zakem, E., Chappell, M. J., Avilés-Vázquez, K., et al. (2007). Organic agriculture and the global food supply. Renewable Agriculture and Food Systems, 22(02), 86-108. https://doi.org/10.1017/S1742170507001640

Barrett, C. B., Reardon, T., \& Webb, P. (2001). Nonfarm income diversification and household livelihood strategies in rural Africa: Concepts, dynamics, and policy implications. Food Policy, 26(4), $315-331$.

Bennett, M., \& Franzel, S. (2013). Can organic and resource-conserving agriculture improve livelihoods? A synthesis. International Journal of Agricultural Sustainability, 11(3), 193-215. https:// doi.org/10.1080/14735903.2012.724925

Bolwig, S., Gibbon, P., \& Jones, S. (2009). The economics of smallholder organic contract farming in tropical Africa. World Development, 37(6), 1094-1104. https://doi.org/10.1016/j.worlddev.2008.09.012

Campbell, D. J., Gichohi, H., Mwangi, A., \& Chege, L. (2000). Land use conflict in Kajiado District, Kenya. Land Use Policy, 17(4), 337-348. https://doi.org/10.1016/S0264-8377(00)00038-7

Chopin, P., Blazy, J.-M., Guindé, L., Tournebize, R., \& Doré, T. (2017). A novel approach for assessing the contribution of agricultural systems to the sustainable development of regions with multi-scale indicators: Application to Guadeloupe. Land Use Policy, 62, 132-142. https://doi.org/10.1016/j. landusepol.2016.12.021

Cohn, A. S., Newton, P., Gil, J. D. B., Kuhl, L., Samberg, L., Ricciardi, V., et al. (2017). Smallholder agriculture and climate change. Annual Review of Environment and Resources. https://doi.org/10. 1146/annurev-environ-102016-060946

Conceição, P., Levine, S., Lipton, M., \& Warren-Rodríguez, A. (2016). Toward a food secure future: Ensuring food security for sustainable human development in Sub-Saharan Africa. Food Policy, 60, 1-9. https://doi.org/10.1016/j.foodpol.2016.02.003

D’Annolfo, R., Gemmill-Herren, B., Amudavi, D., Shiraku, H. W., Piva, M., \& Garibaldi, L. A. (2021). The effects of agroecological farming systems on smallholder livelihoods: A case study on pushpull system from Western Kenya. International Journal of Agricultural Sustainability, 19(1), 56-70. https://doi.org/10.1080/14735903.2020.1822639

Dahlin, A. S., \& Rusinamhodzi, L. (2019). Yield and labor relations of sustainable intensification options for smallholder farmers in sub-Saharan Africa. A meta-analysis. Agronomy for Sustainable Development, 39(3), 32. https://doi.org/10.1007/s13593-019-0575-1

Dantsis, T., Douma, C., Giourga, C., Loumou, A., \& Polychronaki, E. A. (2010). A methodological approach to assess and compare the sustainability level of agricultural plant production systems. Ecological Indicators, 10(2), 256-263. https://doi.org/10.1016/j.ecolind.2009.05.007

Davis, B., Di Giuseppe, S., \& Zezza, A. (2017). Are African households (not) leaving agriculture? Patterns of households' income sources in rural Sub-Saharan Africa. Food Policy, 67, 153-174. https://doi.org/10.1016/j.foodpol.2016.09.018 
Davis, K., \& Place, N. (2003). Current concepts and approaches in agricultural extension in Kenya. In Proceedings of the 19th annual conference of AIAEE. Raleigh, North Carolina, USA (pp. 745-756). https://www.researchgate.net/profile/Nick_Place/publication/228837526_Current_Concepts_and_ Approaches_in_Agricultural_Extension_in_Kenya/links/00b495208ccef7f1f3000000/Current-Conce pts-and-Approaches-in-Agricultural-Extension-in-Kenya.pdf. Accessed 31 August 2017

De Jager, A., Onduru, D., Van Wijk, M. S., Vlaming, J., \& Gachini, G. N. (2001). Assessing sustainability of low-external-input farm management systems with the nutrient monitoring approach: A case study in Kenya. Agricultural Systems, 69(1), 99-118.

de Olde, E. M., Moller, H., Marchand, F., McDowell, R. W., MacLeod, C. J., Sautier, M., et al. (2016). When experts disagree: The need to rethink indicator selection for assessing sustainability of agriculture. Environment, Development and Sustainability. https://doi.org/10.1007/s10668-016-9803-x

Di Falco, S., \& Chavas, J.-P. (2006). Crop genetic diversity, farm productivity and the management of environmental risk in rainfed agriculture. European Review of Agricultural Economics, 33(3), 289-314.

Dolan, C. S. (2004). On farm and packhouse: Employment at the bottom of a global value chain. Rural Sociology, 69(1), 99-126.

Ekbom, A., Knutsson, P., \& Ovuka, M. (2001). Is sustainable development based on agriculture attainable in Kenya? A multidisciplinary case study of Murang'a district. Land Degradation and Development, 12(5), 435-447. https://doi.org/10.1002/1dr.460

El Chami, D., Daccache, A., \& El Moujabber, M. (2020). How can sustainable agriculture increase climate resilience? A systematic review. Sustainability, 12(8), 3119. https://doi.org/10.3390/su12083119

FAO. (2005). Irrigation in Africa in figures, AQUASTAT Survey 2005. FAO Water Reports No. 29. Food and Agriculture Organization of the United Nations.

FAO. (2014). SAFA: sustainability assessment of food and agriculture systems. Version 3.0. Food and Agriculture Organization of the United Nations

Furumo, P. R., Rueda, X., Rodríguez, J. S., \& Parés Ramos, I. K. (2020). Field evidence for positive certification outcomes on oil palm smallholder management practices in Colombia. Journal of Cleaner Production, 245, 118891. https://doi.org/10.1016/j.jclepro.2019.118891

Gebremedhin, B., \& Scott, M. S. (2003). Investment in soil conservation in northern Ethiopia: The role of land tenure security and public programs. Agricultural Economics, 29(1), 69-84. https://doi.org/10. 1016/S0169-5150(03)00022-7

Gichuki, N. N., \& Macharia, J. M. (2006). Socio-economic dimensions of conservation of wetlands in African dry lands: A case study of River Ewaso Ngiro basin in southern Kenya.

Giller, K. E., Witter, E., Corbeels, M., \& Tittonell, P. (2009). Conservation agriculture and smallholder farming in Africa: The heretics' view. Field Crops Research, 114(1), 23-34. https://doi.org/10.1016/j. fcr.2009.06.017

GoK. (2009). Agricultural Sector Development Strategy (ASDS), 2009-2020.

Grenz, J., Thalmann, C., Stämpfli, A., Studer, C., \& Häni, F. (2009). RISE-a method for assessing the sustainability of agricultural production at farm level. Rural Development News, 1(2009), 5-9.

Guinée, J. B., Heijungs, R., Huppes, G., Zamagni, A., Masoni, P., Buonamici, R., et al. (2011). Life cycle assessment: Past, present, and future. Environmental Science and Technology, 45(1), 90-96. https:// doi.org/10.1021/es101316v

Gyau, A., Mbugua, M., \& Oduol, J. (2016). Determinants of participation and intensity of participation in collective action: Evidence from smallholder avocado farmers in Kenya. Journal on Chain and Network Science, 16(2), 147-156. https://doi.org/10.3920/JCNS2015.0011

ILO. (2016). Kenya Decent Work Country Programme 2013-2016. International Labour Organisation. http://www.ilo.org/wcmsp5/groups/public/---ed_mas/---program/documents/genericdocument/wcms_ 561053.pdf. Accessed 29 May 2017

Jama, B. A., Mohamed, A. M., Mulatya, J., \& Njui, A. N. (2008). Comparing the "Big Five": A framework for the sustainable management of indigenous fruit trees in the drylands of East and Central Africa. Ecological Indicators, 8(2), 170-179. https://doi.org/10.1016/j.ecolind.2006.11.009

Kabubo-Mariara, J., Linderhof, V., Kruseman, G., Atieno, R., \& Mwabu, G. (2009). Household welfare, investment in soil and water conservation and tenure security: Evidence from Kenya. https://papers. ssrn.com/sol3/papers.cfm?abstract_id=1527197. Accessed 31 May 2017

Kamau, J. W. (2018). Sustainability of organic and non-organic smallholder farms in Kenya. Bonn University Library (ULB).

Kamau, J. W., Biber-Freudenberger, L., Lamers, J. P. A., Stellmacher, T., \& Borgemeister, C. (2019). Soil fertility and biodiversity on organic and conventional smallholder farms in Kenya. Applied Soil Ecology, 134, 85-97. https://doi.org/10.1016/j.apsoil.2018.10.020 
Kamau, J. W., Stellmacher, T., Biber-Freudenberger, L., \& Borgemeister, C. (2018). Organic and conventional agriculture in Kenya: A typology of smallholder farms in Kajiado and Murang'a counties. Journal of Rural Studies, 57, 171-185. https://doi.org/10.1016/j.jrurstud.2017.12.014

Katto-Andrighetto, J. (2013). Participatory guarantee systems in East Africa: Case studies from Kenya, Tanzania and Uganda. IFOAM Germany, Die Deutsche Bibliothek.

KCDP. (2013). Kajiado County integrated development plan 2013-2017. http://cog.go.ke/images/stories/ CIDPs/Kajiado.pdf. Accessed 20 October 2016

Keeble, B. R. (1988). The Brundtland report: 'Our common future.' Medicine and War, 4(1), 17-25. https:// doi.org/10.1080/07488008808408783

Keizi, L. K. (2006). Barriers to pension scheme participation by workers in the informal sector. Retirement Benefits Authority.

Landert, J., Schader, C., Moschitz, H., \& Stolze, M. (2017). A holistic sustainability assessment method for urban food system governance. Sustainability, 9(4), 490. https://doi.org/10.3390/su9040490

Lekasi, J. K., Tanner, J. C., Kimani, S. K., \& Harris, P. J. C. (2003). Cattle manure quality in Maragua District, Central Kenya: Effect of management practices and development of simple methods of assessment. Agriculture, Ecosystems and Environment, 94(3), 289-298. https://doi.org/10.1016/S01678809(02)00037-3

Ling, C. D. W. (2011). MANOVA: Type I error rate analysis. California Polytechnic State University.

Lukuyu, B., Place, F., Franzel, S., \& Kiptot, E. (2012). Disseminating improved practices: Are volunteer farmer trainers effective? The Journal of Agricultural Education and Extension, 18(5), 525-540. https://doi.org/10.1080/1389224X.2012.707066

Mackenzie, F. (1989). Land and territory: The interface between two systems of land tenure, Muranga District, Kenya. Africa: Journal of the International African Institute, 59(1), 91-109. https://doi.org/10. 2307/1160765

Marandure, T., Bennett, J., Dzama, K., Makombe, G., Gwiriri, L., \& Mapiye, C. (2020). Advancing a holistic systems approach for sustainable cattle development programmes in South Africa: Insights from sustainability assessments. Agroecology and Sustainable Food Systems, 44(7), 827-858. https://doi. org/10.1080/21683565.2020.1716130

Marandure, T., Mapiye, C., Makombe, G., \& Dzama, K. (2017). Indicator-based sustainability assessment of the smallholder beef cattle production system in South Africa. Agroecology and Sustainable Food Systems, 41(1), 3-29. https://doi.org/10.1080/21683565.2016.1231152

Mardia, K. V., Kent, J. T., \& Bibby, J. M. (1979). Multivariate analysis. Academic Press.

Masiga, W. N., \& Munyua, S. J. M. (2005). Global perspectives on animal welfare: Africa. Revue Scientifique Et Technique-Office International Des Epizooties, 24(2), 579.

Mathauer, I., Schmidt, J.-O., \& Wenyaa, M. (2008). Extending social health insurance to the informal sector in Kenya. An assessment of factors affecting demand. The International Journal of Health Planning and Management, 23(1), 51-68. https://doi.org/10.1002/hpm.914

Mati, B. M. (2008). Capacity development for smallholder irrigation in Kenya. Irrigation and Drainage, 57(3), 332-340. https://doi.org/10.1002/ird.437

MCDP. (2013). Murang'a County Integrated Development Plan 2013-2017. http://cog.go.ke/images/stories/ CIDPs/Murang'a.pdf. Accessed 20 October 2016

Meemken, E.-M., \& Qaim, M. (2018). Organic agriculture, food security, and the environment. Annual Review of Resource Economics, 10(1), 39-63. https://doi.org/10.1146/annurev-resou rce-100517-023252

Mgbenka, R. (2013). Organic farming as a strategy for climate change adaptation and mitigation in SubSaharan Africa: Implications for policy. Journal of Agricultural Extension. https://doi.org/10.4314/ jae.v16i2.14

Milliken, G. A., \& Johnson, D. E. (2009). Analysis of messy data. Vol. 1: Designed experiments (2nd ed.). Chapman and Hall/CRC.

Mulinge, W., Gicheru, P., Murithi, F., Maingi, P., Kihiu, E., Kirui, O. K., \& Mirzabaev, A. (2016). Economics of land degradation and improvement in Kenya. In E. Nkonya, A. Mirzabaev, \& J. von Braun (Eds.), Economics of land degradation and improvement-A global assessment for sustainable development (pp. 471-498). Springer.

Muller, A., Schader, C., Scialabba, N.E.-H., Brüggemann, J., Isensee, A., Erb, K.-H., et al. (2017). Strategies for feeding the world more sustainably with organic agriculture. Nature Communications, 8(1), 1290. https://doi.org/10.1038/s41467-017-01410-w

Muriithi, K. M., Huka, S. G., \& Njati, C. I. (2014). Factors influencing growth of dairy farming business in amentia south district of mere county, Kenya. IOSR Journal of Business and Management, 16(4), 21-31. 
Mutuku, M. M., Nguluu, S., Akuja, T., Lutta, M., \& Pelletier, B. (2017). Factors that influence adoption of integrated soil fertility and water management practices by smallholder farmers in the semi-arid areas of Eastern Kenya. Tropical and Subtropical Agroecosystems, 20(1), 141-153.

Ndukhu, O., Onwonga, N., Wahome, G., Kironchi, G., \& Jensen, H. (2016). Assessment of organic farmers' knowledge and adaptation strategies to climate change and variability in Central Kenya. British Journal of Applied Science and Technology, 17(6), 1-22. https://doi.org/10.9734/BJAST/2016/16270

Ndungu, S. K., Macharia, I., Kahuthia-Gathu, R., \& Wahome, R. G. (2013). Impact of organic vegetable production system in Kiambu and Kajiado counties of Kenya. Journal of Environmental Science and Engineering, A2(4), 256-266.

Ngigi, M., Mueller, U., \& Birner, R. (2016). Gender differences in climate change perceptions and adaptation strategies: An intra-household analysis from rural Kenya. https://papers.ssrn.com/sol3/papers. cfm?abstract_id=2747856. Accessed 29 August 2017

Niggli, U., Willer, H., \& Baker, B. (2016). A global vision and strategy for organic farming research. http:// orgprints.org/28520/. Accessed 10 November 2016

Njiru, B. N. (2012). Climate change, resource competition, and conflict amongst pastoral communities in Kenya. In J. Scheffran, M. Brzoska, H. G. Brauch, P. M. Link, \& J. Schilling (Eds.), Climate change human security and violent conflict (pp. 513-527). Springer. https://doi.org/10.1007/978-3-64228626-1_24

Nshakira-Rukundo, E., Kamau, J. W., \& Baumüller, H. (2021). Determinants of uptake and strategies to improve agricultural insurance in Africa: A review. Environment and Development Economics. https://doi.org/10.1017/S1355770X21000085

Nzila, C., Dewulf, J., Spanjers, H., Tuigong, D., Kiriamiti, H., \& van Langenhove, H. (2012). Multi criteria sustainability assessment of biogas production in Kenya. Applied Energy, 93, 496-506. https://doi. org/10.1016/j.apenergy.2011.12.020

Odhong, C., Wahome, R. G., Vaarst, M., Kiggundu, M., Nalubwama, S., Halberg, N., \& Githigia, S. (2014). Challenges of conversion to organic dairy production and prospects of future development in integrated smallholder farms in Kenya. Livestock Research for Rural Development, 26(7), 14-21.

Ogutu, J. O., Piepho, H.-P., Said, M. Y., \& Kifugo, S. C. (2014). Herbivore dynamics and range contraction in Kajiado County Kenya: Climate and land use changes, population pressures, governance, policy and human-wildlife conflicts. The Open Ecology Journal, 7(1), 9-31. https://doi.org/10.2174/18742 13001407010009

Onduru, D. D., \& Du Preez, C. C. (2008). Farmers' knowledge and perceptions in assessing tropical dryland agricultural sustainability: Experiences from Mbeere District, Eastern Kenya. The International Journal of Sustainable Development and World Ecology, 15(2), 145-152.

Otieno, D. J. (2012). Market and non-market factors influencing farmers' adoption of improved beef cattle in arid and semi-arid areas of Kenya. Journal of Agricultural Science, 5(1), 32. https://doi.org/10. $5539 /$ jas.v5n1p32

Ovuka, M. (2000). More people, more erosion? Land use, soil erosion and soil productivity in Murang'a district, Kenya. Land Degradation and Development, 11(2), 111-124. https://doi.org/10.1002/(SICI) 1099-145X(200003/04)11:2\%3c111::AID-LDR371\%3e3.0.CO;2-I

Pérez-Lombardini, F., Mancera, K. F., Suzán, G., Campo, J., Solorio, J., \& Galindo, F. (2021). Assessing sustainability in cattle Silvopastoral systems in the Mexican tropics using the SAFA framework. Animals, 11(1), 109. https://doi.org/10.3390/ani11010109

Place, F. (2009). Land tenure and agricultural productivity in Africa: A comparative analysis of the economics literature and recent policy strategies and reforms. World Development, 37(8), 1326-1336. https:// doi.org/10.1016/j.worlddev.2008.08.020

Pretty, J. N. (1995). Regenerating agriculture: Policies and practice for sustainability and self-reliance. Joseph Henry Press.

Radwan, S. (1995). Challenges and scope for an employment-intensive growth strategy. World, 73, 21-45.

Raynolds, L. T., Murray, D., \& Heller, A. (2007). Regulating sustainability in the coffee sector: A comparative analysis of third-party environmental and social certification initiatives. Agriculture and Human Values, 24(2), 147-163. https://doi.org/10.1007/s10460-006-9047-8

Rees, D., Momanyi, M., Wekundah, J., Ndungu, F., Odondi, J., Oyure, A. O., et al. (2000). Agricultural knowledge and information systems in Kenya: implications for technology dissemination and development. Overseas development institute (ODI). Agricultural Research and Extension Network (AgREN).

Sachs, J., Remans, R., Smukler, S., Winowiecki, L., Andelman, S. J., Cassman, K. G., et al. (2010). Monitoring the World's agriculture. Nature Comments and Opinion. https://doi.org/10.1038/466558a

Salami, A., Kamara, A. B., \& Brixiova, Z. (2010). Smallholder agriculture in East Africa: Trends, constraints and opportunities. London: African Development Bank. 
Samberg, L. H., Gerber, J. S., Ramankutty, N., Herrero, M., \& West, P. C. (2016). Subnational distribution of average farm size and smallholder contributions to global food production. Environmental Research Letters, 11(12), 124010. https://doi.org/10.1088/1748-9326/11/12/124010

Schader, C., Baumgart, L., Landert, J., Muller, A., Ssebunya, B., Blockeel, J., et al. (2016). Using the sustainability monitoring and assessment routine (SMART) for the systematic analysis of trade-offs and synergies between sustainability dimensions and themes at farm level. Sustainability, 8(3), 274. https://doi.org/10.3390/su8030274

Schader, C., Grenz, J., Meier, M. S., \& Stolze, M. (2014). Scope and precision of sustainability assessment approaches to food systems. Ecology and Society, 19, 3. https://doi.org/10.5751/ES-06866-190342

Schaller, N. (1993). The concept of agricultural sustainability. In Agriculture and the environment (pp. 89-97). Elsevier. https://doi.org/10.1016/B978-0-444-89800-5.50010-5

Schwindenhammer, S. (2016). Authority pooling and regional organic agriculture standard-setting: Evidence from East Africa. Journal of Environmental Policy and Planning, 18(1), 102-120. https://doi. org/10.1080/1523908X.2015.1053109

Shepherd, K. D., \& Soule, M. J. (1998). Soil fertility management in west Kenya: Dynamic simulation of productivity, profitability and sustainability at different resource endowment levels. Agriculture, Ecosystems and Environment, 71(1), 131-145. https://doi.org/10.1016/S0167-8809(98)00136-4

Singh, M., \& Maharjan, K. L. (2017). Crop diversification under organic and conventional farming systems. In Sustainability of organic farming in Nepal (pp. 103-112). Springer. https://doi.org/10.1007/ 978-981-10-5619-2_7

Skinner, C. J. (2016). Probability Proportional to Size (PPS) Sampling. In Wiley StatsRef: Statistics reference online (pp. 1-5). American Cancer Society. https://doi.org/10.1002/9781118445112.stat03346. pub2

Spaling, H., Montes, J., \& Sinclair, J. (2011). Best practices for promoting participation and learning for sustainability: Lessons from community-based environmental assessment in Kenya and Tanzania. Journal of Environmental Assessment Policy and Management, 13(03), 343-366. https://doi.org/10. 1142/S1464333211003924

Ssebunya, B. R., Schader, C., Baumgart, L., Landert, J., Altenbuchner, C., Schmid, E., \& Stolze, M. (2019). Sustainability performance of certified and non-certified smallholder coffee farms in Uganda. Ecological Economics, 156, 35-47. https://doi.org/10.1016/j.ecolecon.2018.09.004

StataCorp. (2015). Stata statistical software: Release 14. StataCorp LP.

UN General Assembly. (2014). Open working group proposal for sustainable development goals. United Nations General Assembly.

Van Cauwenbergh, N., Biala, K., Bielders, C., Brouckaert, V., Franchois, L., Garcia Cidad, V., et al. (2007). SAFE-A hierarchical framework for assessing the sustainability of agricultural systems. Agriculture, Ecosystems and Environment, 120(2-4), 229-242. https://doi.org/10.1016/j.agee.2006.09.006

WFP. (2016). Comprehensive Food Security and Vulnerability Survey: Summary report Kenya. World Food Programme.

Winter, E., Marton, S. M. R. R., Baumgart, L., Curran, M., Stolze, M., \& Schader, C. (2020). Evaluating the sustainability performance of typical conventional and certified coffee production systems in Brazil and Ethiopia based on expert judgements. Frontiers in Sustainable Food Systems, 4, 49. https://doi. org/10.3389/fsufs. 2020.00049

World Bank. (2013). Technical assessment of the Kenya national safety net program for results. World Bank.

WRMA. (2013). The national water master plan 2030. Final report-volume I executive summary. Kenya: Water Resources Management Authority.

Publisher's Note Springer Nature remains neutral with regard to jurisdictional claims in published maps and institutional affiliations. 


\section{Authors and Affiliations}

Juliet Wanjiku Kamau' ${ }^{10}$. Christian Schader ${ }^{2}$. Lisa Biber-Freudenberger ${ }^{1}$. Till Stellmacher ${ }^{1}$. David M. Amudavi ${ }^{3}$. Jan Landert ${ }^{2}$. Johan Blockeel ${ }^{2}$. Cory Whitney ${ }^{1,4} \cdot$ Christian Borgemeister $^{1}$

1 Center for Development Research (ZEF), University of Bonn, Genscherallee 3, 53113 Bonn, Germany

2 Research Institute of Organic Agriculture (FiBL), 5070 Frick, Switzerland

3 Biovision Africa Trust (BvAT), c/o icipe, P.O. Box 30772-00100, Nairobi, Kenya

4 Institute of Crop Science and Resource Conservation (INRES)-Horticultural Sciences, University of Bonn, Auf dem Huegel 6, 53121 Bonn, Germany 